OECDpublishing

THE LONG GAME:

FISCAL OUTLOOKS TO

2060 UNDERLINE NEED

FOR STRUCTURAL

REFORM

OECD ECONOMIC

POLICY PAPER

October 2021 No. 29 
Economic Policy Paper No. 29

\section{THE LONG GAME: FISCAL OUTLOOKS TO 2060 UNDERLINE NEED FOR STRUCTURAL REFORM}

This paper has been prepared by:

Yvan Guillemette

David Turner 
The OECD Economic Policy Paper Series is published on the responsibility of the Secretary-General of the OECD. The opinions expressed and arguments employed herein do not necessarily reflect the official views of the Organisation or of the governments of its member countries.

Series: OECD Economic Policy Papers

SSN 2226583X

The statistical data for Israel are supplied by and under the responsibility of the relevant Israeli authorities. The use of such data by the OECD is without prejudice to the status of the Golan Heights, East Jerusalem and Israeli settlements in the West Bank under the terms of international law.

This document and any map included herein are without prejudice to the status of or sovereignty over any territory, to the delimitation of international frontiers and boundaries and to the name of any territory, city or area.

(c) OECD 2021

You can copy, download or print OECD content for your own use, and you can include excerpts from OECD publications, databases and multimedia products in your own documents, presentations, blogs, websites and teaching materials, provided that suitable acknowledgment of OECD as source and copyright owner is given. All requests for public or commercial use and translation rights should be submitted to rights@oecd.org. Requests for permission to photocopy portions of this material for public or commercial use shall be addressed directly to the Copyright Clearance Center (CCC) at info@copyright.com or the Centre français d'exploitation du droit de copie (CFC) at contact@cfcopies.com. 
An earlier version of this paper was discussed at a meeting of Working Party No.1 (WP1) of the OECD Economic Policy Committee. The authors would like to thank the meeting participants, as well as Luiz de Mello, Alain de Serres and Sebastian Turban for comments on earlier versions of the paper. The authors would also like to thank Veronica Humi for editorial assistance and Jeroen Meyer for database assistance.

Selected series from the baseline scenario are available at https://stats.oecd.org/Index.aspx?DataSetCode=EO109 LTB

Other series, as well as data for the alternative scenarios, are available upon request by writing to EcoOutlook@oecd.org.

The following papers present previous versions of long-run scenarios:

Guillemette, Y. and D. Turner (2018), "The Long View: Scenarios for the World Economy to 2060", OECD Economic Policy Papers, No. 22, OECD Publishing, Paris.

OECD (2014), "Growth Prospects and Fiscal Requirements over the Long Term", in OECD Economic Outlook, Volume 2014 Issue 1, OECD Publishing, Paris.

Johansson A. et al. (2013), "Long-Term Growth Scenarios", OECD Economics Department Working Papers, No. 1000, OECD Publishing, Paris.

The following are background papers with methodological details on the long-term global model:

Guillemette, Y. (2019), "Recent improvements to the public finance block of the OECD's long-term global model”, OECD Economics Department Working Papers, No. 1581, OECD Publishing, Paris.

Guillemette, Y., A. de Mauro and D. Turner (2018), "Saving, Investment, Capital Stock and Current Account Projections in Long-Term Scenarios", OECD Economics Department Working Papers,

No. 1461, OECD Publishing, Paris.

Guillemette, Y. and D. Turner (2017), "The fiscal projection framework in long-term scenarios", OECD Economics Department Working Papers, No. 1440, OECD Publishing, Paris.

Guillemette, Y. et al. (2017), "A revised approach to productivity convergence in long-term scenarios", OECD Economics Department Working Papers, No. 1385, OECD Publishing, Paris.

Cavalleri, M. and Y. Guillemette (2017), "A revised approach to trend employment projections in longterm scenarios", OECD Economics Department Working Papers, No. 1384, OECD Publishing, Paris. 


\section{Table of contents}

The long game: fiscal outlooks to 2060 underline need for structural reform 9

1. Introduction 9

2. Progress in living standards in the baseline scenario 10

2.1. Following the pandemic-induced drop and rebound, trend growth is projected to resume its gradual slowdown in both OECD and G20 emerging economies 10

2.2. Living standards continue to progress along current trends 11

2.3. The contribution of legislated increases in statutory retirement ages 16

3. Alternative growth scenarios for OECD countries 18

3.1. Higher trend labour efficiency growth 18

3.2. Reaching for best practices on labour market policies 18

3.3. Additional increases in statutory retirement ages 20

3.4. Boosting public investment 21

4. Despite low interest rates, OECD countries face long-run fiscal pressures 21

4.1. Quantifying long-run fiscal pressures 22

4.2. Historically low interest rates make additional debt finance feasible in many countries $\quad 30$

5. Alternative scenarios illustrate interest rate risks as well as the potential fiscal dividends from structural reforms

5.1. Sensitivity to interest rates 31

5.2. Fiscal dividends from structural reforms 34

\section{References 38}

Annex. The growth projection and accounting framework 42

\section{Tables}

Table 1. The sources of potential real GDP per capita growth in the baseline scenario

\section{Figures}

Figure 1. The baseline scenario in a snapshot $\quad 11$

Figure 2. Trend labour efficiency remains the main growth engine in the baseline scenario 12

Figure 3. Per cent change in real GDP per capita from 2021 to $2060 \quad 15$

Figure 4. Convergence in living standards in the baseline scenario 16

Figure 5. Average effective retirement ages are below normal retirement ages in many countries 17

Figure 6. Legislated increases in statutory retirement ages support living standards 17

Figure 7. Impact of raising trend labour efficiency growth from 1\% to 2\% on OECD GDP per capita 18

Figure 8. Impact of labour market reforms on OECD trend real GDP per capita 19

Figure 9. Labour market reforms would boost living standards $\quad 19$

Figure 10. Additional increases in statutory retirement ages would support living standards 21

Figure 11. The $r-g$ differential crucial to debt dynamics remains favourable in the baseline scenario 23 
Figure 12. Stylised debt trajectories for the OECD are worrisome

Figure 13. Potential future fiscal pressure to keep public debt ratio at current level in the baseline scenario 27

Figure 14. Net interest payments remain low through 2060 in the baseline scenario 30

Figure 15. Net interest payments are projected to increase moderately in most countries 31

Figure 16. One percentage point lower/higher interest rates than in the baseline scenario moderately impacts

projected fiscal pressure, except in high-debt countries

Figure 17. The impact of higher interest rates on net interest payments depends on net debt ratios

Figure 18. Labour market reforms would help alleviate future fiscal pressure

Figure 19. Potential future fiscal pressure to keep public debt ratio at current level with reforms to labour

market and retirement policies 1

Boxes

Box 1. Projections of public expenditure in the long-term model and the fiscal pressure indicator

Box 2. Revisions to projected increases in fiscal pressure since 2018 study 


\section{Abstract/Résumé}

\section{The long game: fiscal outlooks to 2060 underline need for structural reform}

This paper updates the long-term scenarios to 2060 last published in July 2018, with a special focus on fiscal sustainability and risks. In a baseline economic and fiscal scenario, trend real GDP growth for the OECD + G20 area declines from around 3\% post-COVID to $1 \frac{1}{2}$ per cent in 2060, mainly due to a deceleration of large emerging-market economies. Meanwhile, secular trends such as population ageing and the rising relative price of services will keep adding pressure on government budgets. Without policy changes, maintaining current public service standards and benefits while keeping public debt ratios stable at current levels would increase fiscal pressure in the median OECD country by nearly 8 percentage points of GDP between 2021 and 2060, and much more in some countries. Policy scenarios show that reforms to labour market and retirement policies could help boost living standards and alleviate future fiscal pressures. An ambitious reform package combining labour market reforms to raise employment rates with reforms to eliminate early retirement pathways and keep effective retirement ages rising by two thirds of future gains in life expectancy could halve the projected increase in fiscal pressure in the median country, even after taking into account future spending pressures associated with ageing.

Keywords: long-term projection, long-term scenario, fiscal sustainability, fiscal pressure, labour market reform, retirement age

JEL Classification: O4, H68, J11, E6

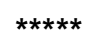 \\ Le jeu long: les perspectives budgétaires à l'horizon 2060 soulignent la nécessité des réformes structurelles}

Ce document met à jour les scénarios à long terme jusqu'en 2060 publiés pour la dernière fois en juillet 2018, avec un accent particulier sur la viabilité et les risques budgétaires. Dans un scénario économique et budgétaire de référence, la croissance tendancielle du PIB réel de la zone OCDE + G20 passe d'environ $3 \%$ après COVID à $1 \frac{11}{2} \%$ en 2060 , principalement en raison d'une décélération des grandes économies de marché émergentes. Pendant ce temps, les tendances séculaires telles que le vieillissement de la population et la hausse des prix relatifs des services continueront d'accroître la pression sur les budgets gouvernementaux. Sans changements de politique, maintenir les normes et les prestations de service public actuelles tout en maintenant les ratios d'endettement public stables aux niveaux actuels augmenterait la pression budgétaire dans le pays médian de l'OCDE de près de 8 points de pourcentage du PIB entre 2021 et 2060 , et bien plus dans certains pays. Les scénarios alternatifs montrent que les réformes du marché du travail et des politiques de retraite pourraient contribuer à améliorer le niveau de vie et à atténuer les futures pressions budgétaires. Un train de réformes ambitieux combinant des réformes du marché du travail visant à augmenter les taux d'emploi et des réformes visant à éliminer les canaux de départ à la retraite anticipée et à maintenir l'âge effectif de départ à la retraite en hausse des deux tiers des gains futurs d'espérance de vie pourrait réduire de moitié l'augmentation prévue de la pression budgétaire dans le pays médian, même après avoir pris en compte les futures pressions sur les dépenses liées au vieillissement.

Mots-clés : projection à long terme, scénario à long terme, soutenabilité budgétaire, pression budgétaire, réforme du marché du travail, âge de la retraite

Classification JEL: O4, H68, J11, E6 


\section{Main Findings}

This paper updates the baseline long-term scenario to 2060 of Guillemette and Turner (2018[1]), with this time a special focus on fiscal sustainability in OECD countries.

\section{Baseline economic scenario}

- Trend annual real GDP growth for the combined OECD + G20 area gradually declines from around $3 \%$ post-COVID to $1 \frac{1}{2}$ per cent in 2060 , mainly due to a deceleration of large emergingmarket economies. China and India continue to account for most of global growth, with India's contribution surpassing China's in the early 2040s.

- Real GDP per capita growth in the OECD area remains more stable, around 11/4 per cent per annum, well below historical norms. Real GDP per capita growth is projected to slow in most of the G20 emerging-market economies, except those where recent performance has been relatively weak (including Argentina, Brazil and South Africa).

\section{Fiscal sustainability in OECD countries}

- As long as the COVID-19 pandemic is not fully tamed, fiscal policy must continue to support the public health effort and help preserve countries' economic fabric, notably by supporting small businesses and vulnerable workers. Once economic recoveries are well established, however, governments will need to wind down temporary programmes and re-assess long-run fiscal sustainability in the context of higher public debt levels and declining trend growth rates.

- Longer term, despite historically easy financing conditions, secular trends such as population ageing and the rising relative price of services will keep adding pressure on government budgets. Fiscal pressure from these long-run trends dwarf that associated with servicing COVID-legacy public debt.

- Without policy changes, maintaining current public service standards and benefits while keeping public debt ratios stable at current levels could increase fiscal pressure in the median OECD country by nearly 8 percentage points of GDP between 2021 and 2060, and much more in some countries.

- Most OECD countries could finance some of the projected increases in expenditure with additional government debt and still keep net interest payments as a share of GDP within historical norms. This strategy could delay, but not avoid, the need for fiscal consolidation if public debt ratios are to be kept from rising to levels that could impede governments' ability to stabilise economic fluctuations and make needed public investments.

- A permanent one-percentage point increase in global interest rates relative to the baseline scenario would add as much as 1 to $1 \frac{1}{2}$ percentage points of GDP to future fiscal pressure in those OECD countries with the highest net debt positions, such as Greece, Italy and Japan.

\section{Reforms to labour market and retirement policies could alleviate future fiscal pressure}

- Reform packages in OECD countries to improve labour market policy settings toward best practices could raise OECD real GDP per capita growth by $1 / 2$ percentage point at the peak and raise its level (i.e. living standards) by nearly $7 \%$ by 2060 via higher employment ratios. Gains could reach $9-10 \%$ in countries furthest from best practices (e.g. Belgium, France and Italy).

- Such reforms could alleviate future fiscal pressure by about $13 / 4$ percentage points of GDP in the median country by 2060, a fifth of the projected baseline increase. In countries with the most to gain from labour market reforms, the potential reduction in fiscal pressure could reach 45 percentage points of GDP. 
- Policy reforms to close early retirement pathways and keep effective retirement ages rising by two thirds of future gains in life expectancy could raise living standards by another $3 \%$ in the median country, and as much as $5-6 \%$ in Belgium, France and Spain. Such reforms would also yield fiscal dividends: a $1 \frac{1}{2}$ percentage points of GDP reduction in fiscal pressure in the median country and 4-5 percentage points in the most affected countries.

- An ambitious reform package combining labour market reforms to raise employment rates with reforms to eliminate early retirement pathways and keep effective retirement ages rising by two thirds of future gains in life expectancy could halve the projected increase in fiscal pressure by 2060 in the median country. Some countries might be able to keep fiscal pressure around today's levels, even after taking into account future spending increases associated with ageing. 


\section{The long game: fiscal outlooks to 2060 underline need for structural reform}

\section{Introduction}

1. This study presents long-term economic projections for OECD and other G20 countries, building on previous versions of this exercise. ${ }^{1}$ The baseline economic scenario then serves as basis for the analysis of long-run fiscal pressures in OECD countries in view of a number of push and pull factors:

- Public debt burdens had already increased substantially since the Great Recession in many countries and are increasing further due to debt-financed temporary support programmes and the relaxation of normal fiscal rules, which are appropriate responses to the COVID-19 shock.

- Interest rates have been trending down for decades and have come down further in response to the pandemic-induced downturn, allowing governments to carry more public debt while keeping debt service costs low. Interest rates on government debt are generally lower than trend GDP growth across OECD economies.

- Population ageing and the rising relative price of services are expected to place upward pressure on public expenditure, notably on public pensions and health care, in the absence of policy changes.

- Trend growth rates have generally declined due to demographic change and a slowdown in productivity growth and they are projected to keep weakening in the decades ahead in a no-policychange scenario.

The study attempts to put all of these factors together into a conventional economic framework and quantify long-term fiscal challenges and vulnerabilities for OECD countries in a number of scenarios. ${ }^{2}$ The scenarios are highly stylised and their objective is not precision, but rather to obtain reasonable orders of magnitude to compare fiscal outlooks and risks across countries, as well as provide some idea of the potential benefits of further reforms.

2. The key message from the analysis is that in a no-policy-change scenario, population ageing and the rising relative price of public services will keep adding fiscal pressure onto OECD countries in the decades ahead. If financing conditions remain favourable, additional borrowing could absorb some of this pressure. However, letting public debt rise comes with risks and trade-offs, so this strategy cannot permanently sidestep the need for policy reforms. Encouragingly, labour market reforms to raise employment rates, including reforms to length working lives, have the potential to make a substantial dent in future fiscal pressure.

3. Section 2 presents the baseline no-policy change economic scenario for both OECD and non-OECD G20 countries. Section 3 looks at scenarios with higher growth from either faster technical

\footnotetext{
${ }^{1}$ Previous versions of long-term scenarios include Johansson et al. (2013[36]), OECD (2014[41]) and Guillemette and Turner $\left(2018_{[1]}\right)$. Other reports examining long-term fiscal sustainability include Turner et al. (1998[42]), Dang, Antolín and Oxley (2001[39]), de la Maisonneuve and Oliveira Martins (2013[38]) and Rouzet et al. (2019[19]).

${ }^{2}$ A lack of comparable fiscal information prevents Chile, Colombia, Costa Rica, Mexico and Turkey from being included in the fiscal analysis of OECD countries.
} 
progress or policy reforms. Section 4 assesses long-run fiscal pressures in the baseline scenario for OECD countries. Finally, section 5 illustrates the sensitivity of baseline fiscal projections to interest rate risk, as well as the fiscal dividends associated with the structural labour market reforms of section 3 , with a special emphasis on raising average effective retirement ages.

\section{Progress in living standards in the baseline scenario}

4. Because it is intended to provide a point of reference for the discussion of other scenarios involving shocks or policy reforms, the baseline scenario assumes essentially no change to initial institutional and policy settings over the projection period, except where already-legislated reforms will have a known impact on the policy indicators used here, such as future changes to statutory retirement ages, which are built into the baseline scenario. In addition, every country is assumed to undertake, as of 2023, a gradual fiscal adjustment sufficient to eventually stabilise government debt as a share of GDP at its projected 2022 level, an assumption which serves to illustrate the magnitude of future fiscal pressure (see section 4). The Annex summarises the main features of the long-term model, provides references with more details and lists a number of important caveats inherent in the use of such a stylised tool.

\subsection{Following the pandemic-induced drop and rebound, trend growth is projected to resume its gradual slowdown in both OECD and G20 emerging economies}

5. The long-run scenarios use as a starting point the final period of the short-run projection horizon from the latest OECD Economic Outlook, currently the year 2022 from the May 2021 edition. A temporary drop in potential growth attributable to the COVID-19 pandemic was projected therein in all major areas (Figure 1, Panel A). This drop reflects a mix of lower trend labour efficiency growth, lower employment ratios and lower capital accumulation due to investment downturns. Potential growth shortfalls between 2020 and 2022 imply permanent negative impacts from the pandemic on potential output levels relative to a pre-pandemic projection, but the long-run scenarios assume no lingering growth effects beyond 2022. This could turn out to be an optimistic assumption if, for instance, the pandemic ushers in a de-globalisation trend, leading to lower trend labour efficiency growth (Arriola et al., 2020[2]). The scenarios also assume that any demand shortfall relative to potential GDP - negative output gap - remaining in 2022 closes gradually thereafter. In all major areas, output gaps are essentially closed by 2024/25.

6. Abstracting from the temporary blip due to the COVID-19 pandemic, in the baseline scenario

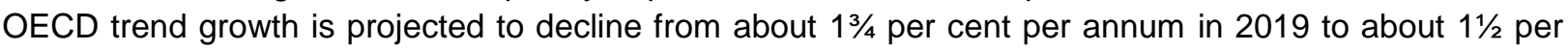
cent in 2030 and then 11/4 per cent by 2045 (Figure 1, Panel A). The growth rate of G20 emerging-market economies falls more markedly, from $4 \frac{1}{2}$ per cent per annum in 2019 to around $3 \%$ by the mid-2030s and $2 \%$ by 2045 , but remains much higher than that of advanced economies. This more dramatic slowdown is largely a consequence of the assumption that trend labour efficiency growth converges to a common value in all countries, but reforms could alter this picture (see below). While the contributions from China and India already dominate global growth, India is projected to surpass China in this respect by the early 2040s, in part because China's population is projected to be falling by then (Figure 1, Panel C and Table 1). China remains the single largest economy throughout the projection period on a purchasing power parity basis, however (Figure 1, Panel B). 
Figure 1. The baseline scenario in a snapshot

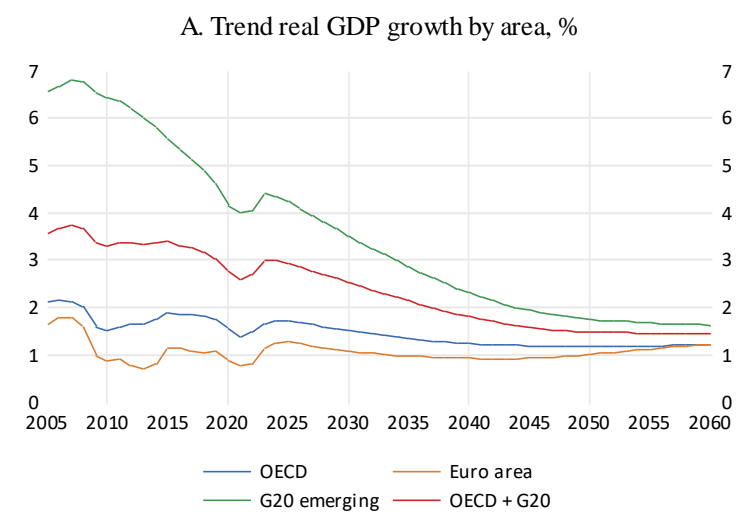

C. OECD + G20 trend real GDP growth decomposition by area, $\%$ pts

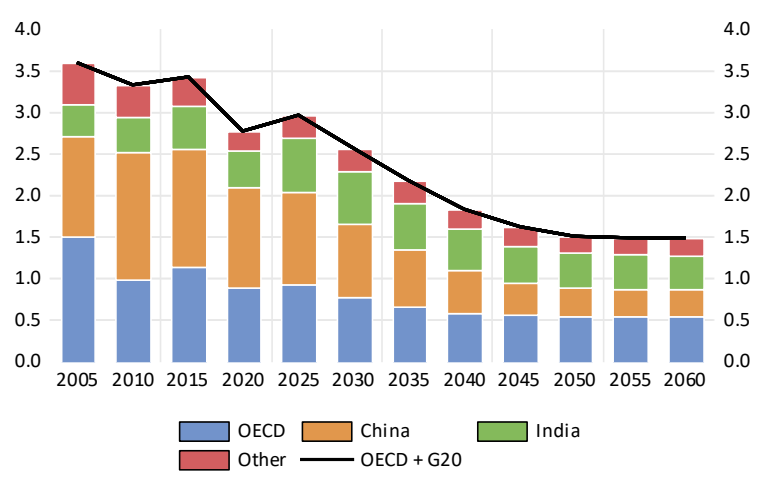

B. Composition of OECD + G20 output, $\%$

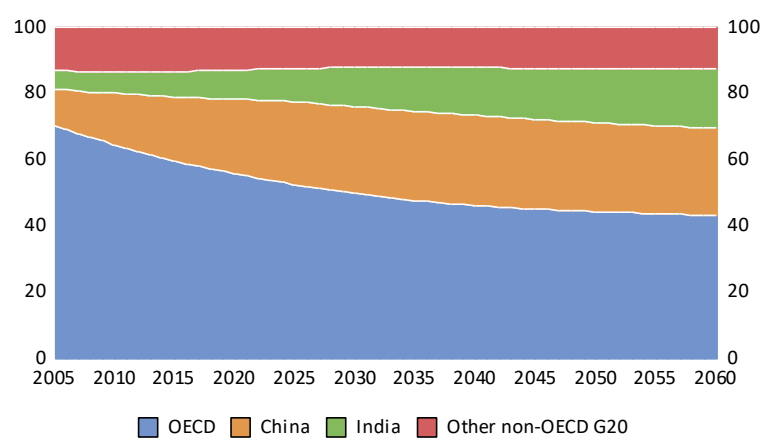

D. OECD + G20 trend real GDP growth decomposition by factor, $\%$ pts

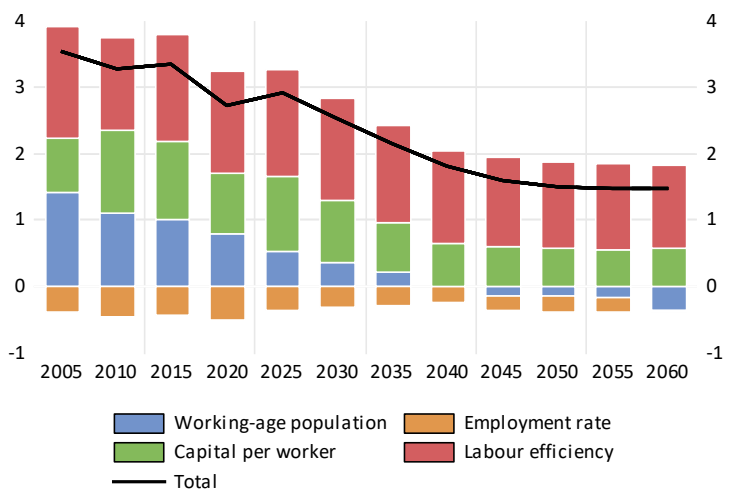

Note: The 'G20 emerging' aggregate in Panel A includes Argentina, Brazil, China, India, Indonesia, Mexico, Russia, Saudi Arabia, Turkey and South Africa. The 'OECD + G20' aggregate includes all OECD and non-OECD G20 countries. In all panels output is measured in USD at 2015 Purchasing Power Parities.

\subsection{Living standards continue to progress along current trends}

7. Slowing headline GDP growth partly reflects slowing population growth. At the global (OECD + G20) level, working-age population growth turns negative by the mid-2040s (Figure 1, Panel D). GDP per capita allows a better assessment of the relative performances of economies and implications for living standards. On this metric, OECD-area real GDP per capita growth remains more stable, around 1-11/4 per cent per annum, but this is well below rates before the Great Recession (Figure 2, Panel A). This pattern reflects a declining contribution from labour, which is partly offset by a modest recovery in labour productivity (via both labour efficiency and capital intensity):

- The declining contribution from labour is mostly explained by ageing: the overall share of the population that is of working age (15-74) has already started declining in the OECD area and, despite rising female employment, growth in the aggregate employment rate decelerates as the share of older cohorts in the working-age population rises. This implies a marked turnaround in the overall labour input (combining both employment rate and share of active population), from recently contributing about $1 / 3$ percentage point per annum to growth in OECD living standards, it turns neutral by 2030 and eventually subtracts more than a tenth of a percentage point per annum post2040 (Figure 2, Panel A). This demographic drag starts sooner and is up to thrice as severe in the euro area (Figure 2, Panel B). Turkey is an important exception within the OECD, with rising female employment rates more than offsetting the effects of ageing on the labour component (Table 1). 
- The modest recovery in OECD productivity growth reflects different trends and assumptions: an assumption that frontier growth in labour efficiency continues at the post-Great Recession trend of around $1 \%$ per annum ${ }^{3}$; continued catch-up in some countries where levels lag behind leaders (notably Eastern European countries and Baltic states); and a recovery in productivity growth in those countries where it has recently been particularly weak, so that they do not fall further behind the frontier (including many in the euro area ${ }^{4}$, Figure 2, Panel B). Differences across countries in labour efficiency growth toward the end of the projection period are essentially due to differences in the progress of average educational attainment (Table 1).

Figure 2. Trend labour efficiency remains the main growth engine in the baseline scenario

Trend real GDP per capita growth, per cent

A. OECD

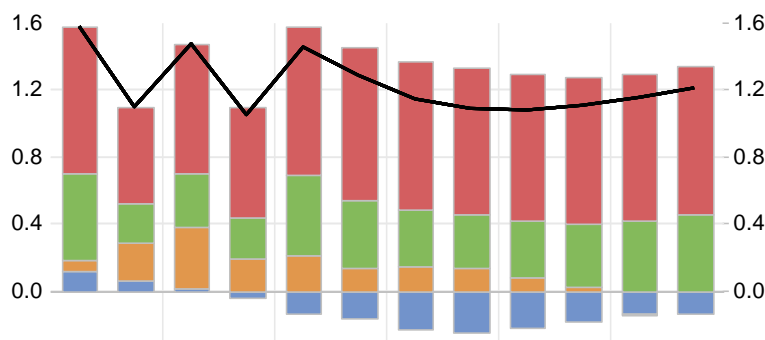

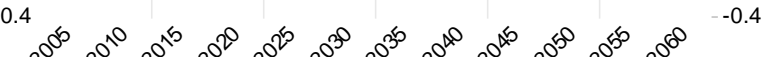

C. G20 emerging

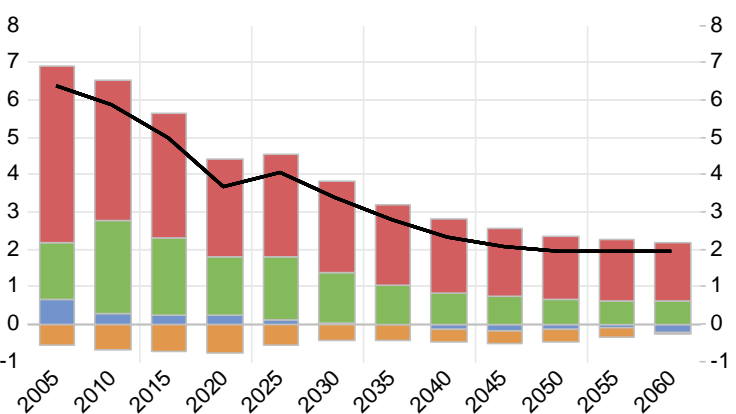

B. Euro area

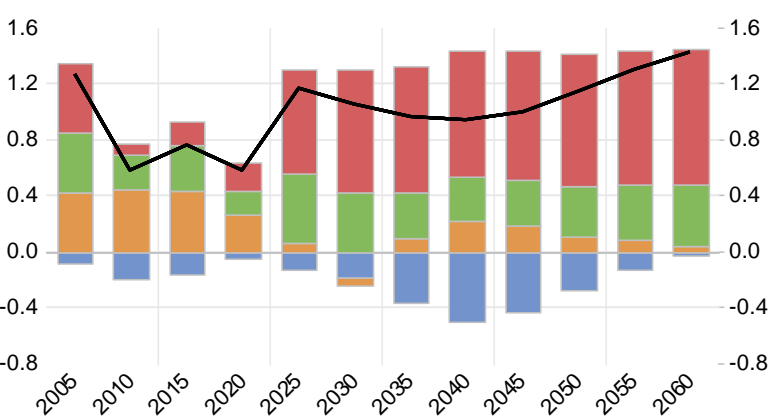

D. $\mathrm{OECD}+\mathrm{G} 20$

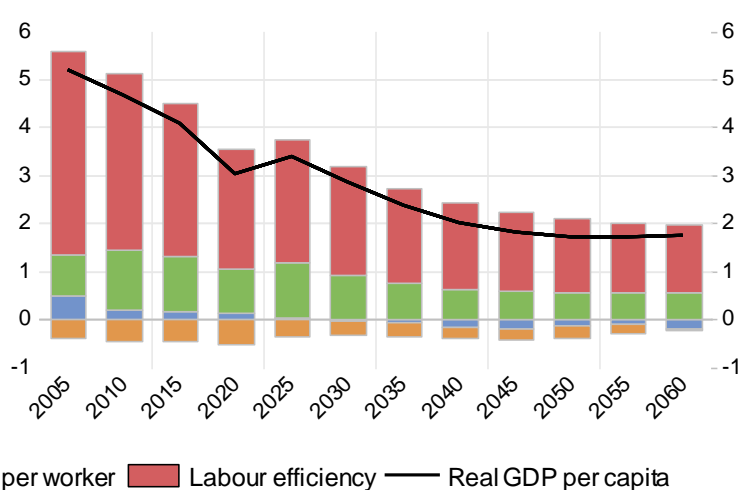

Note: The 'G20 emerging' aggregate in Panel C includes Argentina, Brazil, China, India, Indonesia, Mexico, Russia, Saudi Arabia, Turkey and South Africa. The 'OECD + G20' aggregate in Panel D includes all OECD and non-OECD G20 countries.

\footnotetext{
${ }^{3}$ The previous set of long-run scenarios used a $1.5 \%$ assumption for annual labour efficiency growth in equilibrium, so this represents a significant downward revision, justified by the persistence of the slowdown in productivity growth following the Great Recession. Section 3.1 examines a scenario with faster equilibrium trend labour efficiency growth.

${ }^{4}$ Trend labour efficiency growth in the euro area through 2060 is projected to be similar, but slightly weaker (by about 0.1 pp per annum), than in the latest European Commission Ageing Report (European Commission, 2018[37]). The same is true for trend real GDP per capita growth.
} 
Table 1. The sources of potential real GDP per capita growth in the baseline scenario

Per cent per annum

\begin{tabular}{|c|c|c|c|c|c|c|c|c|c|c|c|c|c|c|c|c|c|c|c|c|}
\hline \multirow[b]{3}{*}{ Australia } & \multirow{2}{*}{\multicolumn{4}{|c|}{$\begin{array}{c}\text { Potential GDP per capita } \\
2000-072007-202020-302030-60\end{array}$}} & \multirow{2}{*}{\multicolumn{4}{|c|}{$\begin{array}{c}\text { Trend labour efficiency } \\
2000-072007-20 \quad 2020-30 \quad 2030-60\end{array}$}} & \multirow{2}{*}{\multicolumn{4}{|c|}{$\begin{array}{c}\text { Capital per worker } \\
2000-072007-20 \quad 2020-302030-60\end{array}$}} & \multirow{2}{*}{\multicolumn{4}{|c|}{$\begin{array}{c}\text { Potential employment rate } \\
2000-072007-202020-302030-60\end{array}$}} & \multicolumn{4}{|c|}{ Share of active population } \\
\hline & & & & & & & & & & & & & & & & & $2000-0$ & $007-2$ & $2020-3$ & $2030-60$ \\
\hline & 1.8 & 1.1 & 0.9 & 1.2 & 0.6 & 0.3 & 0.6 & 0.9 & 0.5 & 0.6 & 0.4 & 0.4 & 0.6 & 0.2 & 0.1 & 0.0 & 0.1 & -0.1 & -0.2 & -0.1 \\
\hline Austria & 1.8 & 0.6 & 0.8 & 1.0 & 0.7 & 0.0 & 0.6 & 0.9 & 0.5 & 0.2 & 0.4 & 0.3 & 0.4 & 0.4 & -0.1 & 0.0 & 0.1 & 0.0 & -0.1 & -0.2 \\
\hline Belgium & 1.6 & 0.7 & 1.0 & 1.1 & 0.3 & 0.0 & 0.5 & 0.9 & 0.8 & 0.6 & 0.7 & 0.3 & 0.6 & 0.1 & -0.2 & 0.0 & -0.1 & -0.1 & -0.1 & -0.2 \\
\hline Canada & 1.6 & 0.8 & 0.7 & 0.8 & 0.6 & 0.4 & 0.6 & 0.7 & 0.4 & 0.4 & 0.3 & 0.2 & 0.4 & 0.0 & 0.1 & 0.0 & 0.2 & 0.0 & -0.3 & -0.2 \\
\hline Chile & 3.0 & 2.1 & 1.4 & 0.9 & 0.2 & -0.2 & 0.6 & 0.9 & 1.5 & 1.4 & 0.8 & 0.3 & 0.7 & 0.5 & 0.1 & 0.0 & 0.6 & 0.3 & 0.0 & -0.2 \\
\hline Colombia & 1.7 & 2.7 & 1.6 & 1.1 & 0.8 & 0.7 & 0.6 & 0.9 & 0.6 & 1.1 & 1.1 & 0.4 & -0.4 & 0.3 & -0.2 & -0.1 & 0.6 & 0.6 & 0.1 & -0.1 \\
\hline Costa Rica & 3.2 & 2.5 & 2.0 & 1.3 & 1.4 & 1.2 & 1.0 & 1.0 & 0.5 & 0.8 & 0.6 & 0.5 & 0.4 & 0.1 & 0.3 & 0.0 & 0.9 & 0.4 & 0.1 & -0.2 \\
\hline Czech Republic & 3.2 & 2.1 & 1.9 & 1.1 & 2.3 & 1.6 & 1.6 & 1.1 & 0.6 & 0.3 & 0.5 & 0.5 & 0.1 & 0.4 & 0.2 & -0.1 & 0.2 & -0.3 & -0.4 & -0.3 \\
\hline Denmark & 1.0 & 0.9 & 1.1 & 1.1 & 0.4 & 0.7 & 0.9 & 0.9 & 0.5 & 0.3 & 0.4 & 0.4 & 0.1 & -0.1 & 0.1 & 0.0 & 0.0 & 0.0 & -0.4 & -0.1 \\
\hline Estonia & 6.3 & 2.3 & 2.9 & 1.0 & 2.8 & 0.8 & 1.4 & 0.8 & 2.6 & 1.1 & 1.2 & 0.3 & 0.7 & 0.9 & 0.3 & 0.1 & 0.2 & -0.4 & 0.0 & -0.3 \\
\hline Finland & 2.2 & 0.6 & 1.1 & 1.2 & 1.2 & 0.1 & 0.7 & 0.9 & 0.3 & 0.2 & 0.4 & 0.4 & 0.7 & 0.3 & 0.2 & 0.1 & 0.0 & -0.1 & -0.2 & -0.1 \\
\hline France & 1.0 & 0.7 & 0.9 & 1.2 & 0.4 & 0.2 & 0.6 & 0.9 & 0.5 & 0.3 & 0.4 & 0.4 & 0.2 & 0.1 & 0.1 & 0.1 & -0.2 & 0.0 & -0.2 & -0.2 \\
\hline Germany & 1.2 & 1.1 & 0.8 & 0.9 & 0.6 & 0.5 & 0.7 & 0.8 & 0.2 & 0.0 & 0.3 & 0.3 & 0.2 & 0.9 & 0.0 & 0.1 & 0.1 & -0.3 & -0.2 & -0.2 \\
\hline Greece & 1.8 & -0.6 & 1.3 & 1.2 & 0.5 & -1.0 & 0.4 & 0.9 & 0.7 & -0.1 & 0.4 & 0.4 & 1.0 & 0.7 & 0.4 & 0.4 & -0.4 & -0.2 & 0.1 & -0.5 \\
\hline Hungary & 3.0 & 2.5 & 2.4 & 0.9 & 1.6 & 1.0 & 1.1 & 0.9 & 1.0 & 0.5 & 0.7 & 0.4 & 0.2 & 1.1 & 0.9 & -0.1 & 0.1 & -0.1 & -0.3 & -0.3 \\
\hline Iceland & 2.7 & 1.1 & 1.1 & 1.2 & 1.5 & 1.1 & 0.9 & 0.9 & 0.9 & -0.1 & 0.3 & 0.4 & 0.0 & 0.0 & 0.0 & 0.0 & 0.2 & 0.1 & 0.0 & -0.2 \\
\hline Ireland & 2.2 & 3.6 & 2.0 & 1.0 & 0.1 & 0.9 & 1.2 & 1.0 & 1.3 & 2.8 & 0.7 & 0.4 & 0.6 & 0.1 & -0.1 & 0.0 & 0.1 & -0.2 & 0.2 & -0.3 \\
\hline Israel & 1.7 & 1.5 & 1.3 & 1.4 & 0.9 & 0.7 & 0.7 & 1.0 & 0.0 & 0.2 & 0.5 & 0.3 & 0.7 & 0.6 & 0.0 & 0.1 & 0.0 & -0.1 & 0.0 & 0.0 \\
\hline Italy & 0.3 & -0.2 & 0.7 & 1.2 & -0.4 & -0.3 & 0.5 & 1.0 & 0.4 & -0.1 & 0.3 & 0.4 & 0.7 & 0.4 & 0.0 & 0.1 & -0.3 & -0.1 & 0.0 & -0.3 \\
\hline Japan & 0.5 & 0.7 & 1.0 & 1.1 & 0.4 & 0.3 & 0.6 & 0.9 & 0.4 & -0.1 & 0.2 & 0.4 & 0.0 & 0.8 & 0.6 & 0.1 & -0.3 & -0.4 & -0.4 & -0.4 \\
\hline Korea & 3.8 & 2.8 & 1.9 & 0.8 & 1.8 & 1.2 & 0.9 & 1.0 & 1.4 & 0.9 & 0.9 & 0.4 & 0.3 & 0.5 & 0.3 & 0.1 & 0.4 & 0.2 & -0.2 & -0.7 \\
\hline Latvia & 7.4 & 2.9 & 2.8 & 1.0 & 2.6 & 1.0 & 1.4 & 0.8 & 3.8 & 1.5 & 1.1 & 0.3 & 0.7 & 0.9 & 0.4 & 0.1 & 0.3 & -0.5 & -0.1 & -0.2 \\
\hline Lithuania & 7.2 & 3.5 & 2.6 & 0.9 & 4.1 & 1.2 & 1.2 & 0.8 & 2.9 & 1.3 & 1.2 & 0.2 & -0.2 & 1.3 & 0.3 & 0.1 & 0.4 & -0.3 & -0.2 & -0.3 \\
\hline Luxembourg & 2.0 & 0.6 & 0.9 & 1.2 & 0.2 & -0.3 & 0.6 & 1.0 & 0.1 & 0.0 & 0.2 & 0.5 & 1.7 & 0.6 & 0.2 & 0.0 & 0.0 & 0.3 & -0.1 & -0.3 \\
\hline Mexico & 0.7 & 1.1 & 1.1 & 1.5 & 0.0 & 0.4 & 0.7 & 0.9 & -0.1 & 0.0 & 0.0 & 0.5 & 0.1 & 0.2 & 0.1 & 0.1 & 0.6 & 0.5 & 0.3 & 0.0 \\
\hline Netherlands & 1.4 & 0.8 & 0.9 & 1.1 & 0.7 & 0.4 & 0.7 & 0.9 & 0.2 & 0.2 & 0.4 & 0.3 & 0.5 & 0.2 & 0.2 & 0.1 & 0.0 & 0.1 & -0.3 & -0.2 \\
\hline New Zealand & 2.1 & 1.5 & 1.3 & 1.3 & 0.5 & 0.6 & 0.8 & 0.9 & 0.4 & 0.3 & 0.5 & 0.4 & 0.9 & 0.5 & 0.1 & 0.1 & 0.2 & 0.0 & -0.1 & -0.1 \\
\hline Norway & 2.3 & 1.0 & 0.8 & 1.1 & 1.5 & 0.5 & 0.6 & 0.9 & 0.3 & 0.3 & 0.4 & 0.4 & 0.2 & 0.0 & 0.0 & 0.0 & 0.2 & 0.2 & -0.1 & -0.2 \\
\hline Poland & 3.5 & 3.3 & 2.4 & 1.0 & 2.0 & 1.6 & 1.6 & 1.0 & 0.8 & 1.0 & 0.8 & 0.4 & 0.4 & 0.8 & 0.3 & -0.1 & 0.3 & -0.1 & -0.4 & -0.4 \\
\hline Portugal & 1.1 & 0.9 & 1.6 & 1.3 & -0.2 & 0.2 & 0.7 & 1.2 & 1.3 & 0.6 & 0.7 & 0.4 & 0.1 & 0.1 & 0.4 & 0.1 & -0.1 & -0.1 & -0.2 & -0.4 \\
\hline Slovakia & 6.1 & 2.5 & 1.8 & 1.3 & 4.6 & 1.5 & 1.3 & 1.2 & 0.6 & 0.4 & 0.6 & 0.5 & 0.4 & 0.7 & 0.1 & -0.2 & 0.5 & -0.1 & -0.3 & -0.4 \\
\hline Slovenia & 2.8 & 1.6 & 1.6 & 1.1 & 1.4 & 1.2 & 1.2 & 1.0 & 1.0 & 0.1 & 0.6 & 0.4 & 0.5 & 0.6 & 0.0 & 0.0 & 0.0 & -0.4 & -0.2 & -0.4 \\
\hline Spain & 1.6 & 0.5 & 1.1 & 1.1 & -0.1 & 0.2 & 0.7 & 1.0 & 0.7 & 0.5 & 0.4 & 0.4 & 1.2 & 0.0 & 0.0 & 0.3 & -0.3 & -0.2 & 0.0 & -0.6 \\
\hline Sweden & 2.2 & 0.9 & 1.1 & 1.0 & 1.6 & 0.5 & 0.6 & 0.9 & 0.4 & 0.3 & 0.5 & 0.3 & -0.2 & 0.2 & 0.1 & -0.1 & 0.4 & -0.1 & -0.1 & -0.1 \\
\hline Switzerland & 1.3 & 0.8 & 0.9 & 1.1 & 0.6 & 0.4 & 0.7 & 0.9 & 0.3 & 0.1 & 0.3 & 0.4 & 0.2 & 0.4 & 0.0 & 0.0 & 0.2 & 0.0 & -0.2 & -0.2 \\
\hline Turkey & 3.2 & 3.9 & 3.1 & 1.9 & 1.5 & 1.5 & 1.2 & 1.1 & 1.6 & 1.1 & 0.9 & 0.5 & -0.2 & 1.0 & 0.8 & 0.5 & 0.4 & 0.3 & 0.2 & -0.1 \\
\hline United Kingdom & 1.5 & 0.7 & 0.8 & 0.9 & 0.7 & 0.0 & 0.4 & 0.8 & 0.5 & 0.5 & 0.4 & 0.3 & 0.1 & 0.3 & 0.1 & 0.1 & 0.2 & -0.1 & -0.1 & -0.2 \\
\hline United States & 1.5 & 1.1 & 1.2 & 1.0 & 1.1 & 0.8 & 0.9 & 0.7 & 0.6 & 0.3 & 0.4 & 0.3 & -0.4 & -0.2 & 0.1 & 0.1 & 0.2 & 0.1 & -0.2 & -0.1 \\
\hline Euro area & 1.3 & 0.7 & 1.0 & 1.1 & 0.5 & 0.2 & 0.7 & 0.9 & 0.4 & 0.3 & 0.4 & 0.4 & 0.6 & 0.4 & 0.1 & 0.1 & -0.1 & -0.1 & -0.1 & -0.3 \\
\hline OECD & 1.6 & 1.3 & 1.3 & 1.1 & 0.8 & 0.7 & 0.8 & 0.9 & 0.5 & 0.3 & 0.4 & 0.4 & 0.1 & 0.3 & 0.2 & 0.1 & 0.1 & 0.0 & -0.1 & -0.2 \\
\hline
\end{tabular}

THE LONG GAME: FISCAL OUTLOOKS TO 2060 UNDERLINE NEED FOR STRUCTURAL REFORM @ OECD 2021 
Table 1. The sources of potential real GDP per capita growth in the baseline scenario (contd.)

Per cent per annum

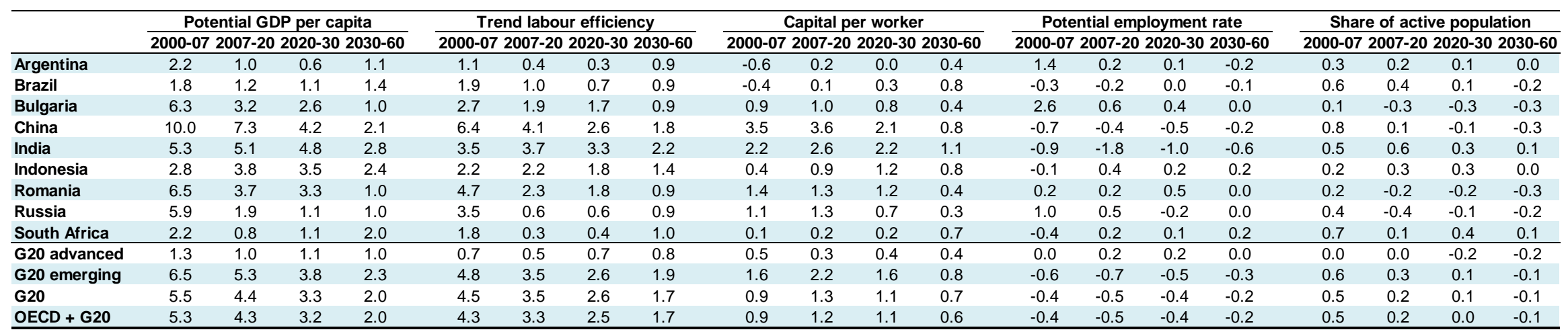

Note: The table reports average geometric growth rates in percentage points per annum. Because of missing data, the starting years for the decomposition is 2001 for Colombia and South Africa, 2002 for Hungary, Lithuania, Romania and G20; and 2003 for Euro area and 'OECD + G20'. 'G20 advanced' includes Australia, Canada, Germany, France, the United Kingdom, Italy, Japan, Korea and the United States. 'G20 emerging' includes Argentina, Brazil, China, India, Indonesia, Mexico, Russia, Saudi Arabia, Turkey and South Africa. The 'OECD + G20' aggregate includes all OECD and non-OECD G20 countries. 
8. Real GDP per capita growth is projected to slow in most of the G20 emerging-market economies, except those where post-Great Recession performance has been relatively weak (including South Africa, Brazil and Argentina).

- In G20 emerging-market economies, the labour component has been a drag on growth since the Great Recession and this trend continues throughout the projection period, subtracting between $1 / 4$ and $1 / 2$ percentage points to growth in living standards, with China and India the main contributors (Figure 2, Panel $C$ and Table 1). The labour input subtracts around $1 / 2$ percentage point per annum from China's GDP per capita growth over the projection period, partly a legacy of the one-child policy, which recent data on birth rates suggest may be difficult to reverse. In India, the issue is not so much demographics as declining employment rates in successive female cohorts, in marked contrast to rising female employment in most other countries. ${ }^{5}$

- Given small, and in some cases negative, employment contributions, labour productivity growth, particularly the labour efficiency component, is the main factor explaining the more optimistic GDP per capita trajectory of the G20 emerging-market economies (Figure 3). Strong, albeit slowing, productivity growth in India, China and Indonesia reflects recent performance and leads to noticeable catch-up in GDP per capita in those countries when benchmarked against the United States (Figure 4). Nevertheless, GDP per capita in India is still only around a third of US levels by 2060. In the other large G20 emerging-market economies (Russia, Brazil, Argentina and South Africa), a continuation of relatively weak productivity performance implies much slower convergence to US living standards.

Figure 3. Per cent change in real GDP per capita from 2021 to 2060

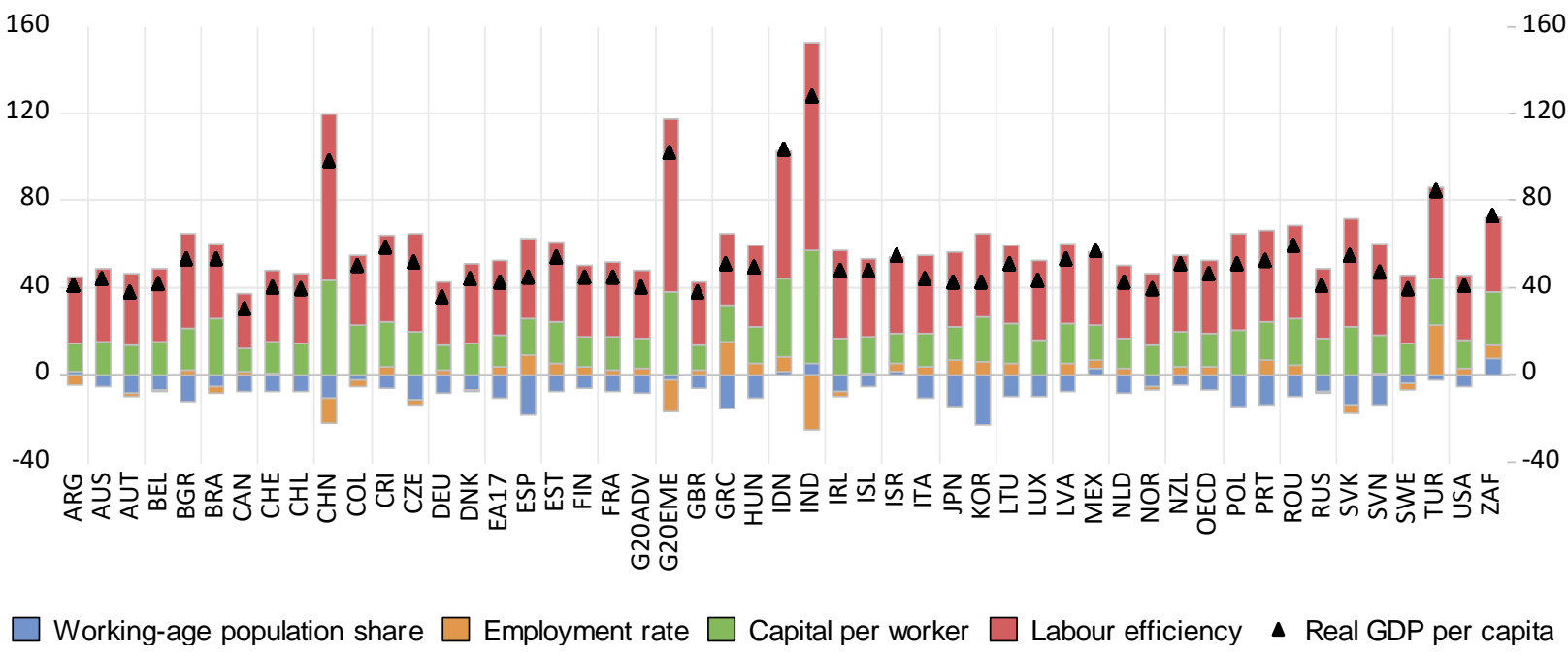

Note: G20ADV refers to 'G20 advanced' and includes Australia, Canada, Germany, France, the United Kingdom, Italy, Japan, Korea and the United States. G20EME refers to 'G20 emerging' and includes Argentina, Brazil, China, India, Indonesia, Mexico, Russia, Saudi Arabia, Turkey and South Africa.

\footnotetext{
${ }^{5}$ Low - and falling - female employment rates in India appear to be due to a number of factors, among which a lack of job growth in female-friendly sectors (e.g. manufacturing), cultural expectations and social stigma, safety concerns, lack of family policies and poor infrastructure. There is, however, evidence of a U-shaped labour market participation curve with respect to income and education. This represents an upside risk to the projected evolution of the female employment rate in India. For further discussion, including policy recommendations, see Chapter 2 in OECD (2014[35]).
} 
Figure 4. Convergence in living standards in the baseline scenario

Real GDP per capita at 2015 Purchasing Power Parities, USA $=100$

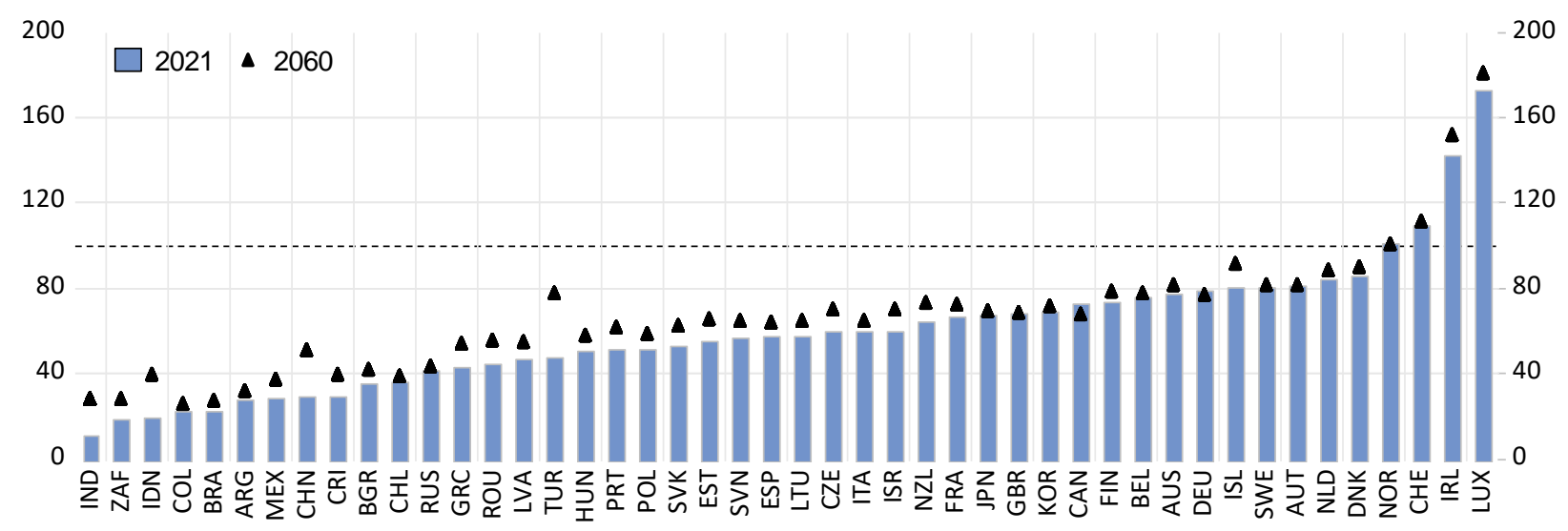

9. Limited progress on living standards in emerging-market economies relative to the US benchmark is not inevitable, but reflects the baseline scenario assumption of no policy change. However, emergingmarket economies could accelerate gains in living standards with reforms to improve some of the fundamental drivers of growth (Ruch, 2020[3]; Kilic Celik, Kose and Ohnsorge, 2020[4]]). In the previous set of long-run scenarios, a reform simulation exercise was considered for Brazil, Russia, India, Indonesia, China and South Africa, the so-called BRIICS countries. It showed that by improving governance, educational attainment and trade openness to median OECD levels over the next 40 years, these countries could boost their living standards by $30 \%$ to $50 \%$ relative to baseline (Guillemette and Turner, $2018_{[1]}$ ). Governance appears as a particularly potent source of potential economic gains in Russia, while Brazil, China and India also have much to gain by boosting educational attainment. The influence of greater trade openness is comparatively small, but largest in Brazil given its relatively high import tariffs.

\subsection{The contribution of legislated increases in statutory retirement ages}

10. As mentioned previously, the baseline scenario takes into account future increases in statutory retirement ages that have already been legislated by governments. ${ }^{6}$ For most countries, a one-year increase in the statutory retirement age is assumed to raise the average effective age of retirement by approximately five months. This assumption is based on new estimation work by the OECD Economics Department and is higher than the typical estimate in the literature based on a multi-country panel approach, which works out to around $2 \frac{1}{2}$ months (Turner and Morgavi, 2021 $[5]$ ). The lower estimate is used in countries where there are good reasons to expect changes to statutory retirement ages to have weaker effects on retirement behaviour than in most countries. In a first set of countries, including the United States, Canada, Ireland and the United Kingdom, voluntary (often private occupational) pension plans account for a higher proportion of gross pension replacement rates than in other countries. ${ }^{7}$ In a second set of countries, including Belgium, France, Italy and Spain, average effective retirement ages are

\footnotetext{
6 The normal statutory retirement age is calculated as the age at which a worker with an uninterrupted career from age 22 could have retired on a full old-age pension in 2018.

7 See Table 5.3 in (OECD, 2019[40]). It is possible that private pension systems eventually respond, possibly with a long lag, to changes in statutory retirement ages in public or compulsory pension systems, by making similar adjustments. If this were the case, then the effect of changing statutory retirement ages may be under-estimated for these countries.
} 
substantially below normal statutory retirement ages, suggesting the availability and/or greater use of alternative pathways into early retirement outside of the old-age pension system (Figure 5).

Figure 5. Average effective retirement ages are below normal retirement ages in many countries

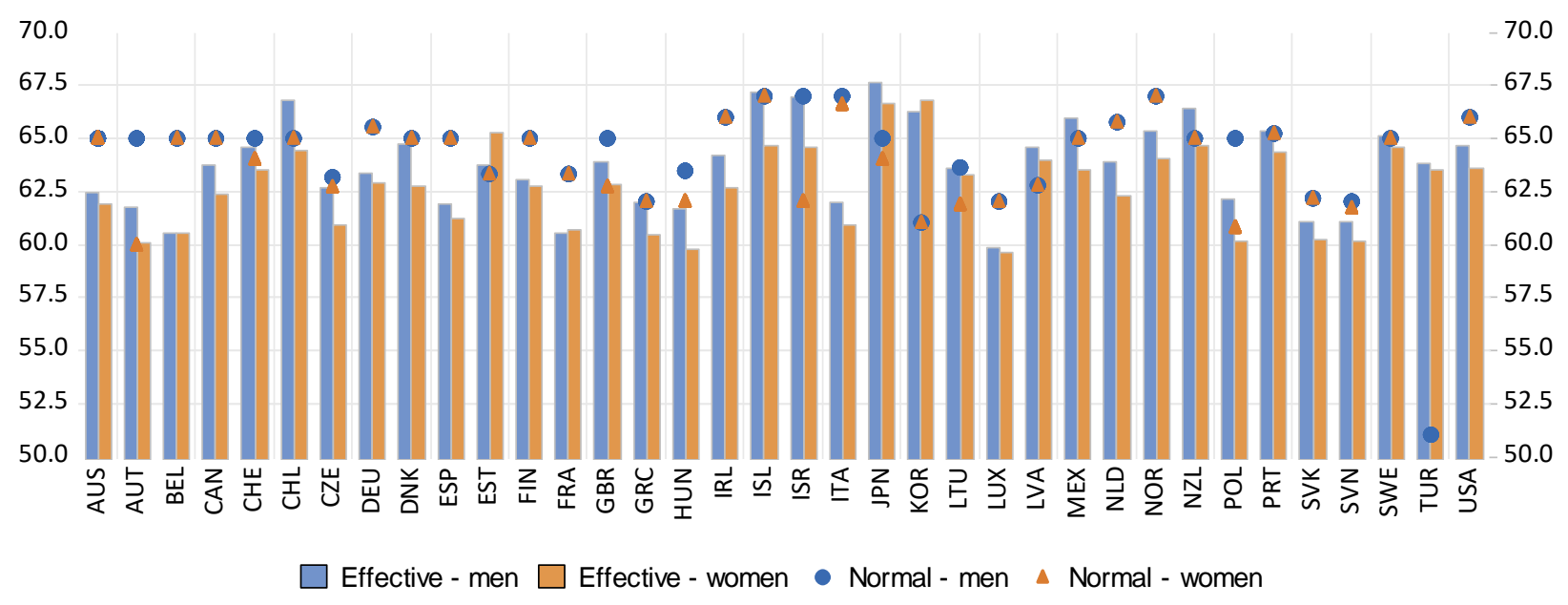

Note: Average effective retirement ages are computed from age and sex-specific employment rates. Normal statutory retirement ages the ages at which a full old-age pension can be drawn for individuals retiring in 2018 after an uninterrupted career starting at age 22.

Source: OECD (2019), Pensions at a Glance 2019: OECD and G20 Indicators, OECD Publishing, Paris, https://dx.doi.org/10.1787/b6d3dcfc-en and secretariat calculations.

11. Countries that have already legislated future increases in statutory retirement ages are projected to benefit from these reforms in terms of higher employment rates among older age groups and thus higher real GDP per capita. In the median country, the gain is estimated at $1 \frac{11}{2}$ per cent by 2060 relative to a scenario where statutory retirement ages remain at current levels (Figure 6). Some of the largest gains, 3$4 \%$ higher GDP per capita, accrue to countries that have linked future increases in statutory retirement ages to increases in life expectancy, like Denmark, Finland and Portugal. Turkey has not formally linked its statutory retirement age to life expectancy, but the government is planning to raise statutory retirement ages substantially for both men and women as of 2036, boosting living standards by $41 / 2$ per cent by 2060 .

\section{Figure 6. Legislated increases in statutory retirement ages support living standards}

Contribution to projected change in real GDP per capita between 2021 and 2060, \% pts

5

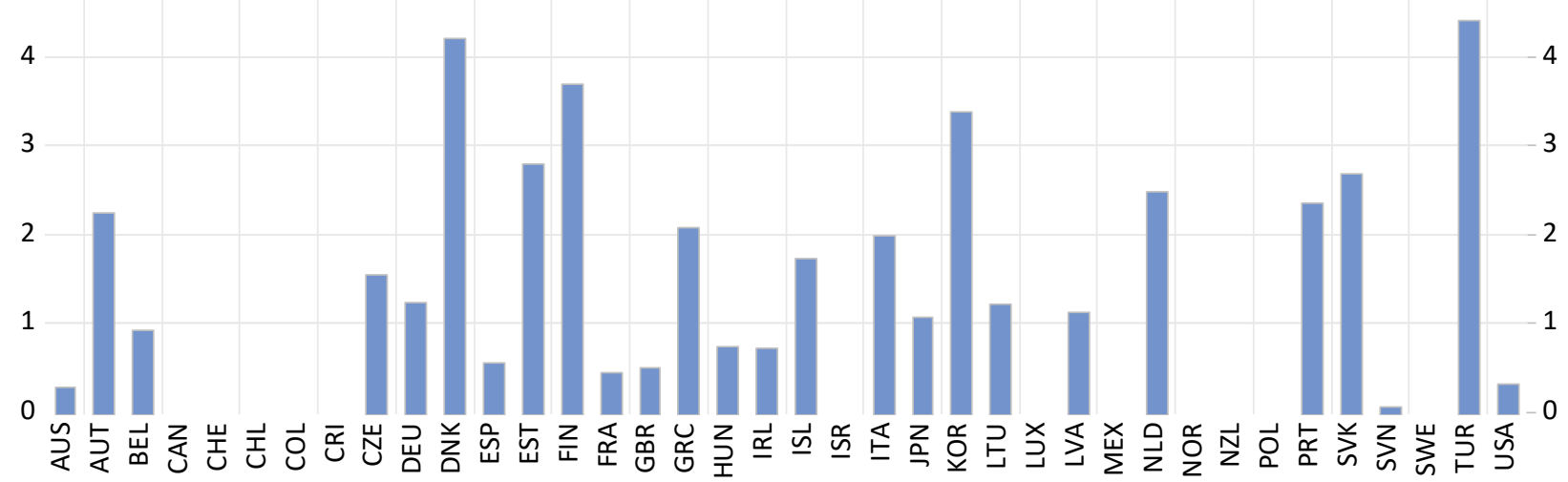

Note: The bars measure contributions of legislated changes in normal statutory retirement ages to changes in real GDP per capita between 2021 and 2060 incorporated in the baseline scenario, relative to a scenario where statutory retirement ages remain at their current levels. 


\section{Alternative growth scenarios for OECD countries}

12. This section describes a few alternative scenarios for OECD countries. These help give a sense of the sensitivity of the long-run projections to some of the basic assumptions and illustrate the potential benefits of structural reforms. Some of these scenarios are reprised in section 5 to examine the sensitivity of the baseline fiscal projection.

\subsection{Higher trend labour efficiency growth}

13. The assumed rate of equilibrium labour efficiency growth in the baseline scenario ( $1 \%$ per annum) is common to all countries and determines trend labour efficiency growth once convergence to the countryspecific trend labour efficiency level is achieved (which can take decades depending on a country's estimated initial distance to equilibrium). This assumption is highly uncertain. While in line with recent lowproductivity outturns, $1 \%$ could be too pessimistic. In an alternative scenario where this parameter is raised to $2 \%$, living standards progress significantly more than in the baseline scenario. The impact is fairly uniform across countries (which is why only the OECD aggregate is shown), gradually raising real GDP per capita growth by 1 percentage point (Figure 7, Panel A) and living standards in 2060 by about one third relative to baseline (Figure 7 , Panel $\mathrm{B}$ ). The scenario is agnostic about the source of higher trend labour efficiency growth, but it could be related to progress in biotechnology, artificial intelligence, industrial automation and more.

\section{Figure 7. Impact of raising trend labour efficiency growth from $1 \%$ to $2 \%$ on OECD GDP per capita}

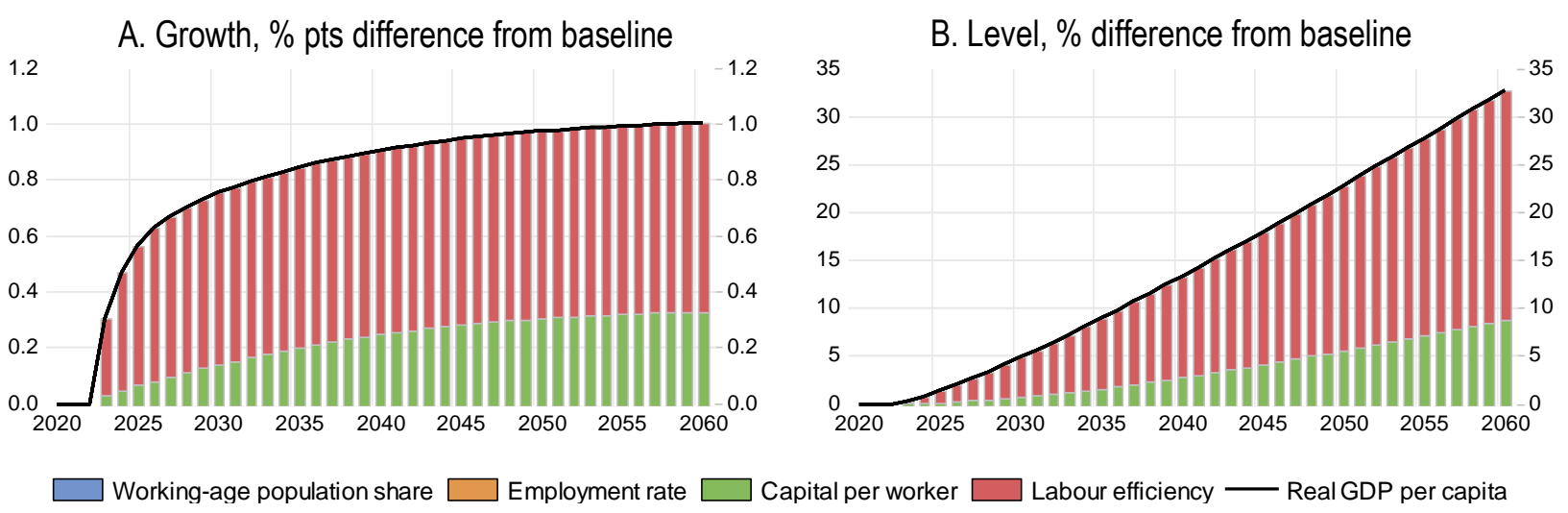

\subsection{Reaching for best practices on labour market policies}

14. A second alternative scenario illustrates potential employment gains if OECD countries would close, by 2030 , half of current gaps on a number of labour market policy indicators relative to the five bestperforming countries. Only half of the gaps are assumed to close in recognition of the difficulty of implementing the implied structural reforms. The assessment uses the impacts of labour market reforms estimated by Gal and Theising (2015[6]) and Égert and Gal (2017[7]).

15. For the median country, the reform package implies the following changes over the 2023-to-2030 period: spending on active labour market policies (ALMP) per unemployed worker rises by 10 percentage points of GDP per capita, public spending on family benefits in kind rises by 0.6 percentage points of GDP, maternity leave increases by 12 weeks, and tax wedges for both single earners and couples decline by about 9 percentage points of labour costs. Specific reform magnitudes depend, for each country and indicator, on gaps relative to best practices according to the latest available data. 
16. The OECD-wide reform effort boosts trend real GDP per capita growth by $1 / 2$ percentage point at the peak toward the end of the reform implementation period (Figure 8, Panel A). The rapidity with which employment reacts implies some temporary reduction in the amount of capital available per worker, hence the slight negative growth contribution from capital intensity initially. This spurs investment to rise and eventually capital intensity also contributes positively to growth. The labour market reforms considered are assumed not to impact trend labour efficiency. OECD average living standards are about $2 \frac{1}{2}$ per cent higher by the time the reforms are fully implemented in 2030 and nearly $7 \%$ higher by 2060 (Figure 8, Panel B). These positive outcomes are driven in large part by gains in female employment. Besides promoting the integration of women in the labour market, better family benefits, longer maternity leaves and lower tax wedges also promote employment among the lower-income segments of the population (OECD, 2017[8]).

\section{Figure 8. Impact of labour market reforms on OECD trend real GDP per capita}

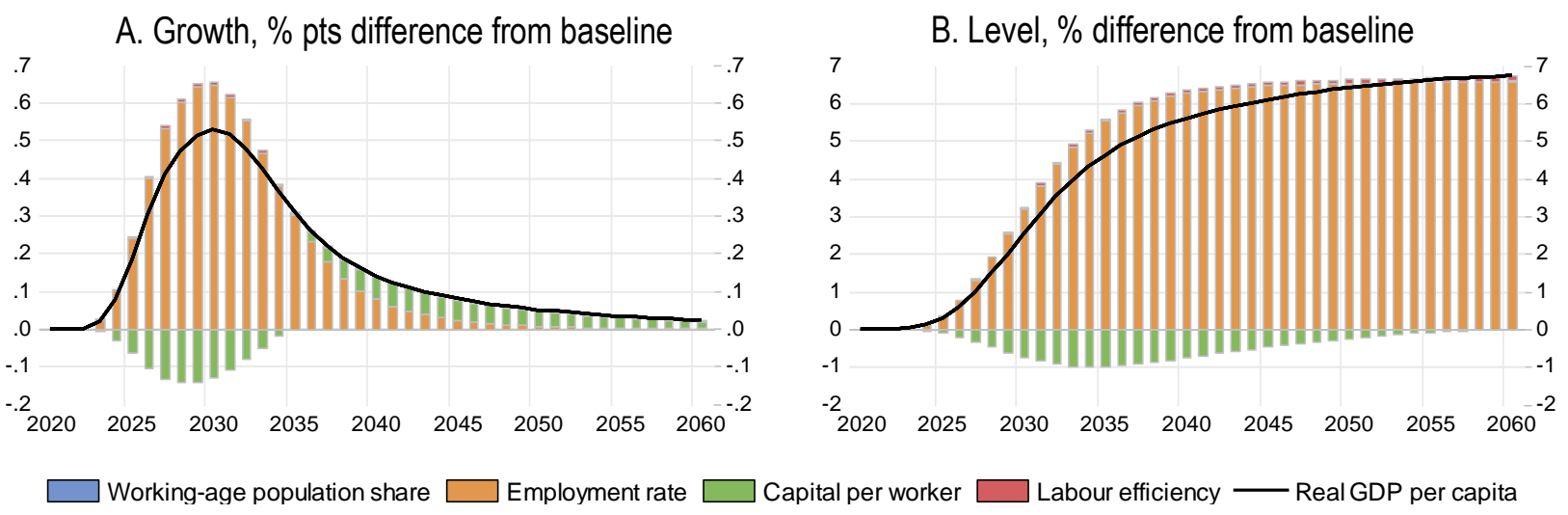

17. By 2060, cumulative improvements in living standards relative to the baseline scenario are as much as $9-10 \%$ in countries that are currently furthest from best practices on the set of labour market policies considered here (Figure 9). It should, however, be noted that many countries, especially in Europe, have implemented labour market reforms in recent years. Because the standard labour market indicators used here are only available with a few years' lag, they may not reflect the most recent reforms.

\section{Figure 9. Labour market reforms would boost living standards}

Per cent difference in trend real GDP per capita in 2060 relative to baseline scenario

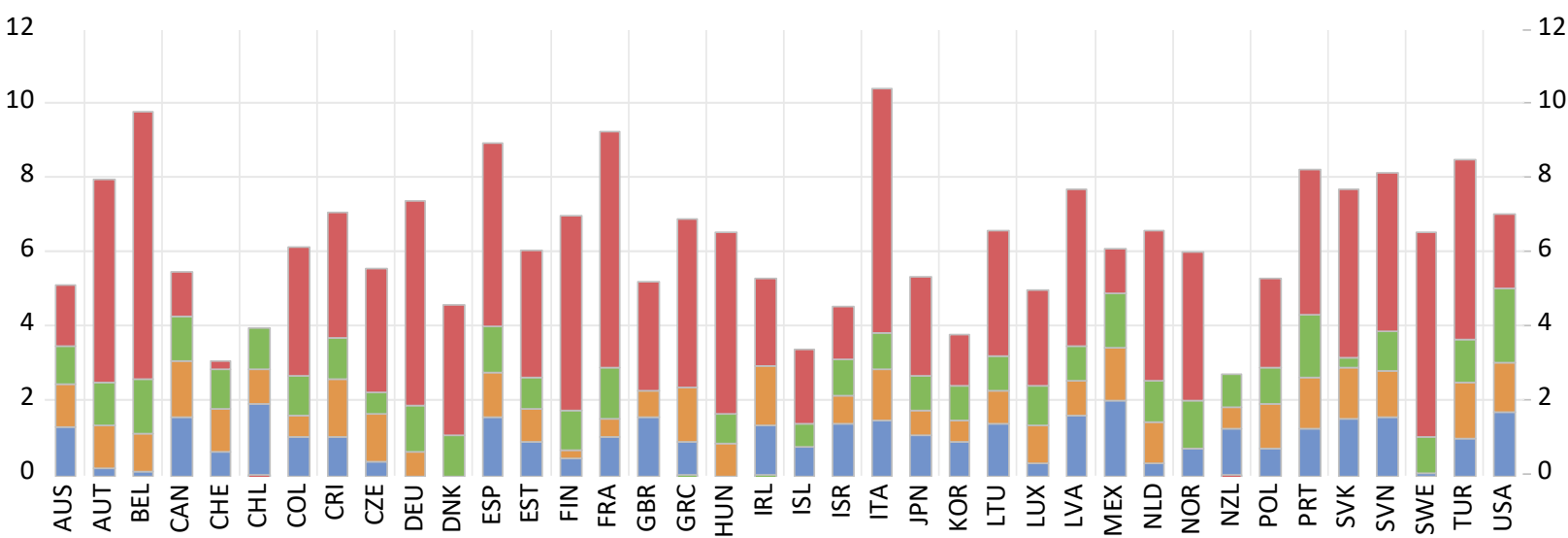

$\square$ ALMP $\square$ Family benefits $\square$ Maternity leave $\square$ Tax wedges 


\subsection{Additional increases in statutory retirement ages}

18. Despite the many reforms to retirement policies across the OECD in recent years, and with the possible exceptions of Estonia and Korea, average effective retirement ages are not projected to keep up with projected gains in life expectancy anywhere in the OECD. Estonia is planning to raise statutory retirement ages for both men and women by $13 / 4$ years by 2026 and link them to life expectancy thereafter, whereas Korea has legislated substantial increases in statutory retirement ages and already has high participation rates at older ages.

19. To illustrate the potential gains from additional reforms to retirement policies, an alternative scenario assumes that governments would undertake policy measures so as to 1) close any initial shortfall between average effective and minimum/normal statutory retirement ages for both men and women; and 2) keep average effective retirement ages rising in the future at a rate equal to two thirds of projected gains in life expectancy if not already the case in the baseline. ${ }^{8}$ Such reforms could include tightening or eliminating pathways into early retirement available in unemployment, disability or other social security programmes outside of the old-age pension system ${ }^{9}$, raising statutory retirement ages more substantially and/or more quickly, lengthening contributory periods necessary to receive a full pension, allowing people to combine income from part-time work with a retirement pension, etc. It could also include measures to encourage employers to retain or hire older workers, retraining programmes to help older workers acquire new skills, programmes to improve health at older ages, or any other measure to facilitate and encourage longer working lives. Limiting future increases to statutory retirement ages to two-thirds of life expectancy gains mimics the Portuguese approach, based on the reasonable idea that part of any future increase in life expectancy should be spent in retirement and not only work.

20. In this alternative scenario, increases in average effective retirement ages raise real GDP per capita in the median country by $3 \%$ in 2060 relative to the baseline scenario (Figure 10). Projected gains are as much as $5-6 \%$ in Belgium, France, Spain and other countries where average effective retirement ages are substantially lower than minimum/normal statutory ages.

\footnotetext{
${ }^{8}$ Average effective and normal statutory retirement ages are shown in Figure 5. The initial shortfall for the scenario is calculated as the difference between the two, if it is negative. However, in some countries, early pension withdrawal is possible, with penalty (see Table 4.4 in OECD $\left(2019_{[40]}\right)$ ). When that is the case, the initial shortfall is calculated as the difference between the average effective and the early retirement age, if it is negative.

${ }^{9}$ Ongoing joint work by the Economics Department and the Directorate for Employment and Social Affairs is attempting to quantify the importance of early retirement pathways in OECD countries historically and estimate their impacts on employment rates at older ages.
} 


\section{Figure 10. Additional increases in statutory retirement ages would support living standards}

Per cent difference in trend real GDP per capita in 2060 relative to baseline scenario

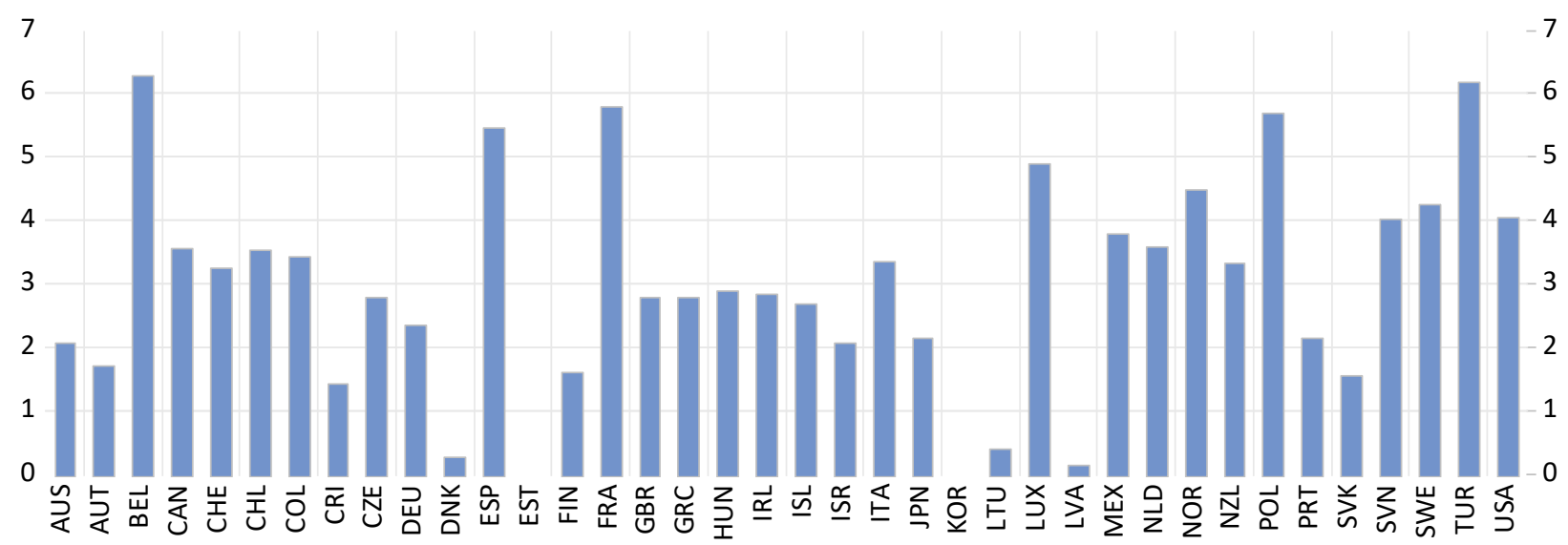

Note: The bars represent potential additional gains from implementing policies that would close any initial shortfall between average effective and normal statutory retirement ages for men and women, as well as keep future increases in average effective retirement ages equal to two thirds of projected gains in life expectancy. When early pension withdrawal is possible (with penalty), the initial shortfall is calculated as the difference between the average effective and the early retirement age, if it is negative.

\subsection{Boosting public investment}

21. Governments' access to very low financing rates, combined with large infrastructure needs in many countries after years of underinvestment, suggest the existence of many positive net return projects that would boost potential output and raise future living standards. The previous set of long-run scenarios analysed an illustrative scenario in which OECD countries gradually and permanently raised public investment to $6 \%$ of GDP by 2030 (Guillemette and Turner, 2018 ${ }_{[1]}$ ). The fiscal effort was around $2 \frac{1}{2}$ percentage points of GDP in the median country relative to baseline investment rates. In this scenario, OECD potential output per capita growth increased by nearly $1 / 4$ percentage point at the peak in 2030 , and while the growth effect subsequently tapered off slowly, the cumulative impact on OECD productive capacity rose throughout the projection period, reaching over $4 \%$ by 2060 . The impacts could be larger in reality because the simulation did not take into account the possibility that judiciously chosen public investment projects could also spur additional private investment.

\section{Despite low interest rates, OECD countries face long-run fiscal pressures ${ }^{10}$}

22. As recommended by the OECD and many others, in the short run, governments should remain focused on reducing COVID-19 infections with vaccination and other public health measures, while supporting affected households and businesses with temporary programmes (OECD, 2021[9]). These programmes should be targeted towards sectors hardest hit by the COVID-19 shock and their phasing out should be contingent on the phasing out of restrictions that limit doing business in these sectors. Given favourable financing conditions and the temporary nature of these programmes, financial markets have accommodated the resulting large increases in government borrowing. Once economic recoveries are well established and support measures have been wound down, however, governments will need to re-assess long-run fiscal sustainability in the context of higher initial government debt levels and declining trend

\footnotetext{
${ }^{10}$ Because of a lack of comparable fiscal information, the fiscal analysis in this paper excludes non-OECD G20 countries, as well as Chile, Colombia, Costa Rica, Mexico and Turkey among OECD countries.
} 
growth rates. This section illustrates the long-run fiscal pressures faced by OECD countries with the use of stylised scenarios.

\subsection{Quantifying long-run fiscal pressures}

23. In any long-run fiscal projection, the difference between the implicit average interest rate on government debt $(r)$ and the potential growth rate $(g)$ is a crucial concept as it determines whether debt as a percentage of GDP would be on an upward, flat or downward trajectory for a given primary budget balance. With $r<g$, governments can afford to run primary deficits without debt necessarily rising as a percentage of GDP. If the primary deficit is large enough, the public debt ratio could rise, but not explosively. It would converge toward a finite value, although this value might well be high and getting there could eventually raise $r$ above $g$ via a risk premium.

24. For the great majority of OECD countries, $r-g$ is estimated to be negative at the start of the long-run projection horizon. Projections of $r-g$ in the long-term model depend on projected potential growth rates, discussed in the previous section, and projected short and long-term interest rates on government debt, which are anchored on a neutral short-term interest rate. There is a lot of uncertainty, however, as to initial (i.e. current) neutral short-term interest rate levels and therefore a lot of space for judgement in modelling choices. In the seminal Laubach and Williams $\left(2003_{[10]}\right)$ model, the natural real interest rate is equal to the economy's trend growth rate plus an unobserved stochastic component that captures other influences. Within this framework, the unobserved component is currently negative, which may reflect excess desired global saving over investment, or a number of other factors (Rachel and Smith, $\left.2015_{[11]}\right)$.

25. In the baseline scenario, this unobserved component is assumed to gradually disappear over the projection period, so that neutral short-term real interest rates gradually converge toward real potential growth. As a result, initial $r-g$ differentials tend to shrink toward zero over time: from -1.7 percentage points in 2021, the median country differential moves to -1.2 percentage points in 2030 and -0.1 percentage points in 2045 (Figure 11). This is consistent with the empirical result of Wyplosz (2019[12]), who finds an average differential of 0.1 percentage point historically using 895 annual observations from 22 OECD countries. Differences across countries in $r-g$ differentials also gradually disappear and what remains is mainly due to country-specific fiscal risk premia in long-term interest rates. ${ }^{11}$

\footnotetext{
${ }^{11}$ See section 5 of Guillemette $\left(2019_{[13]}\right)$ for methodological details on long-term interest rate projections. Because the neutral short-term rate for the euro area is set with respect to euro area potential growth, $r-g$ differentials become slightly positive in euro area countries where potential growth eventually declines below the euro area average.
} 
Figure 11. The $r-g$ differential crucial to debt dynamics remains favourable in the baseline scenario

Difference between implicit average interest rate on government debt and potential growth rate across OECD countries, median and interquartile range in $\%$ pts

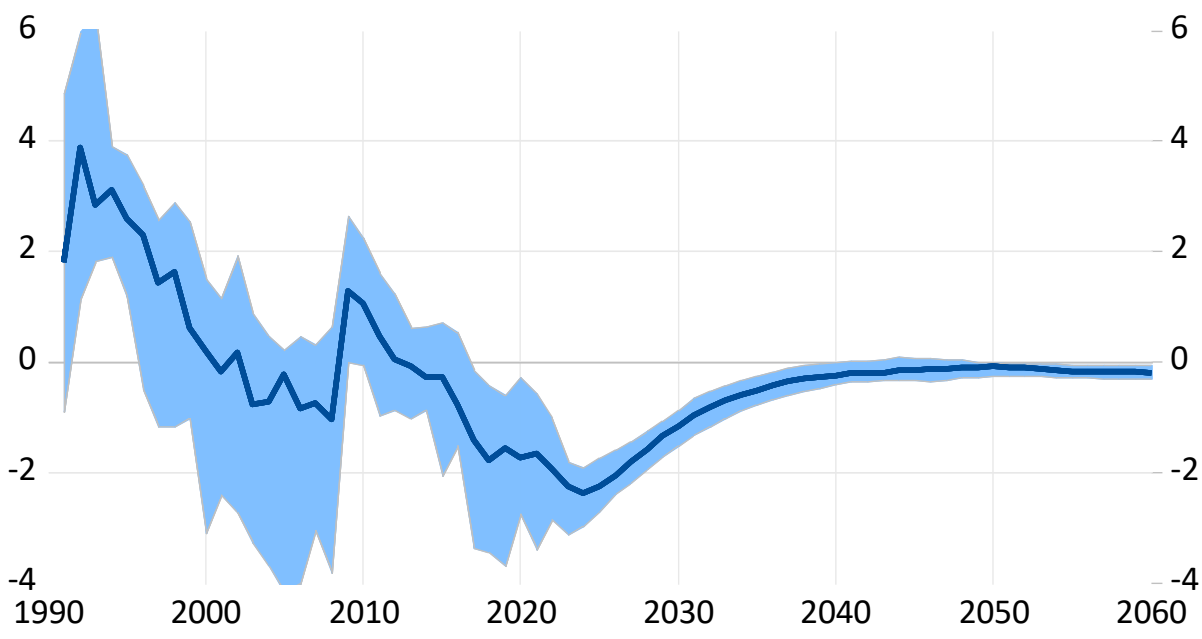

26. The other crucial variable in a long-run fiscal projection is the primary budget balance. It has deteriorated sharply recently in most OECD countries as they responded to the public health crisis with exceptional transfers to households and businesses. Assuming that expenditure on temporary support programmes is gradually scaled back and with no further fiscal consolidation, the OECD structural primary balance would stabilise around $-1 \frac{1}{2}$ per cent of GDP (Figure 12, Panel A). OECD net government debt as a percentage of GDP would then be on an upward path but, given the favourable $r-g$ conditions just outlined, not an explosive one (Figure 12, Panel B). However, when considering expenditure pressures associated with ageing (see Box 1) and assuming that these are not offset by other expenditure cuts or additional revenue, the OECD structural primary balance would deteriorate rapidly and net government debt would more than double as a share of GDP by 2050 (Figure 12).

\section{Figure 12. Stylised debt trajectories for the OECD are worrisome}
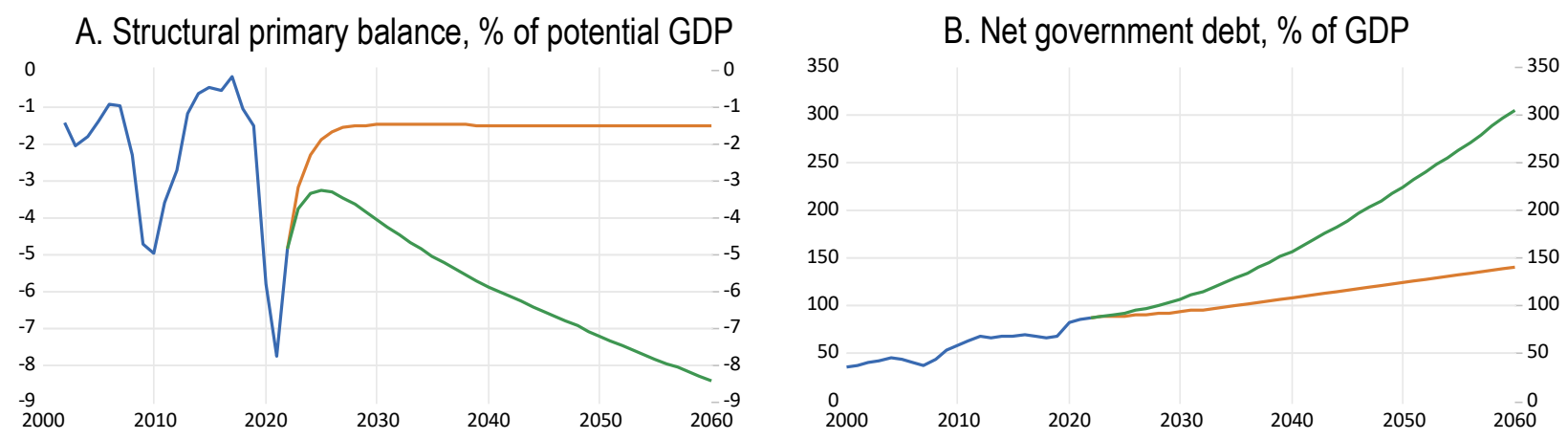

— History and short-run projection —Without ageing costs — With ageing costs

Note: History and short-run projections to 2022 are from the OECD Economic Outlook No. 109 database. The long-run projection without ageing costs assumes that non-health, non-pension structural primary expenditure returns to a pre-COVID baseline over a few years to account for the continued withdrawal of special programmes to support individuals and businesses during the pandemic The long-run projection with ageing costs assumes that expenditure increases due to ageing (see Box 1) are not compensated by additional revenue and lead to a deterioration of the structural primary balance. The charts show OECD aggregates computed from individual OECD country projections, but excluding Colombia, Chile, Mexico and Turkey for lack of comparable data and also Norway given its very large net asset position. 


\section{Box 1. Projections of public expenditure in the long-term model and the fiscal pressure indicator}

The long-term model projects public expenditure using simple reduced-form equations that rely either on coefficients estimated from historical data (health) or on stylised assumptions (pension and other primary expenditure). These equations imply a "business-as-usual" future in which no major policy changes are undertaken. Country specificities in health, pension and other programme designs are generally not taken into account other than in initial expenditure levels, except as specified below.

\section{Public health and long-term care expenditure}

Projected growth in nominal per capita public expenditure on health care (including long-term care) is a function of real GDP per capita growth (income effect), changes in the share of the population aged 65 and over (population ageing effect), the GDP inflation rate and the excess of inflation in the healthcare sector over the broader economy (Baumol effect). This latter effect reflects the cost-pressure phenomenon observed in labour-intensive sectors where labour productivity grows more slowly than in other sectors. It is related in the model to the projected rate of aggregate labour productivity growth, as faster productivity growth implies a stronger Baumol effect. The possible impact of the COVID-19 pandemic on long-run health expenditure is not taken into account in the projections as the latest available information on health spending per capita still pre-dates the pandemic. See section 4 in Guillemette $\left(2019_{[13]}\right)$ for additional methodological details.

\section{Public pension expenditure}

Public pension expenditure is projected on the basis of the projected change in the ratio of retirees to workers and an assumption regarding the evolution of the average benefit ratio (the ratio of the average public pension benefit to the average wage). The evolution of the ratio of retirees to workers depends on the evolution of the population age structure and on projected employment rates by age and sex according to a cohort model, which takes into account already-legislated future changes in statutory retirement ages (see Annex). Based on the observation that the average benefit ratio at the EU level has remained broadly stable over the past two decades, country-specific average benefit ratios are assumed to remain constant over the projection period, except in a few countries where significant pension reforms have recently been enacted. The exceptions are Greece, Spain and Portugal, where relatively high initial benefit ratios are projected to decline toward the current EU average (around $43 \%$ ) by 2060 ; and Brazil where a recent pension reform should reduce benefit generosity over time. In reality, some other countries have introduced affordability rules or other mechanisms in their public pension systems that may imply declines in average benefit ratios over time. See section 3 in Guillemette $\left(2019_{[13]}\right)$ for additional methodological details.

\section{Other primary expenditure}

Other primary expenditure (i.e. excluding health and pensions) is projected based on the assumption that governments will seek to provide a constant level of public spending per capita in real terms. Under some reasonable assumptions, the evolution of this expenditure category relative to GDP becomes a function of the projected evolution of the population-to-employment ratio, as expenditure (numerator) follows population whereas GDP (denominator) follows employment. Expenditure related to exceptional and temporary support programmes during the COVID-19 pandemic is assumed to taper off quickly and does not affect long-run expenditure projections. See section 3.1.2 in Guillemette and Turner $\left(2017_{[14]}\right)$ for more details. 


\section{The fiscal closure rule and the fiscal pressure indicator}

In a long-term model solved over many decades, it is necessary to ensure that the government debt-to-GDP ratio eventually stabilises. To this end, the assumed fiscal rule seeks to stabilise the debt ratio at its initial value (i.e. the projected value for the last year of the short-run horizon of the latest OECD Economic Outlook, currently 2022). It does so by adjusting the ratio of underlying (i.e. cyclicallyadjusted and excluding one-off operations) primary revenue to potential GDP, which can be interpreted as an overall tax rate on the economy and is referred to as fiscal pressure in the main text. Correspondingly, the summary measure of fiscal adjustment used in the paper is the change in this ratio over a given time period, usually 2021 to 2060 .

The fiscal rule implies that this ratio must change over time one-for-one with any projected change in public expenditure as a share of GDP. This allows the projected change in fiscal pressure to be decomposed into the three expenditure categories outlined previously in this box, plus a residual category called 'other factors'. This latter category picks up any disequilibrium between the initial primary balance and the one consistent with keeping the debt ratio stable at the current $r-g$ differential, and also reflects any projected change in this differential over the projection period.

The long-run fiscal adjustment is assumed to begin in 2023 on the basis of the structural fiscal position projected for 2022 in the May 2021 OECD Economic Outlook. A cap on overall fiscal consolidation of one percentage point of potential GDP (measured on the underlying primary balance) in any single year is imposed to reflect political economy constraints. One percentage point is somewhat arbitrary but larger fiscal adjustments have rarely been sustained for more than two or three years. This assumption may contradict current government plans and may not be consistent with national or supra-national fiscal objectives, targets or rules. No allowance is made for Keynesian effects of consolidation on demand. The difference between actual and cyclically-adjusted revenue is pinned down by the output gap (which is assumed to close gradually within a few years) and a semi-elasticity coefficient estimated in previous OECD work (Price, Dang and Botev, 2015[15]). 
27. Whether public debt trajectories for individual countries would be sustainable or not is difficult to say. Much research has demonstrated that fiscal sustainability is a concept fraught with uncertainties (Blanchard, Leandro and Zettelmeyer, 2021 $\left.{ }_{[16]}\right)$. In particular, there are no specific thresholds for government debt, fiscal balances, interest rates or any other indicator beyond which a country's fiscal position can reliably be characterised as unsustainable, as sustainability depends on what happens in the unknowable future. The present study therefore does not attempt such categorisation. Instead, it uses an indicator of long-run fiscal pressure that is premised on the idea that governments would seek to stabilise public debt ratios at projected 2022 levels by adjusting structural primary revenue from 2023 onward (see Box 1 for details on the fiscal pressure indicator). The resulting concept - required change in structural primary revenue over the long run - has several advantages:

- It compares a flow to another flow (revenue to GDP) as opposed to a stock to a flow (e.g. debt to GDP);

- By relying on structural concepts (i.e. cyclically-adjusted primary revenue and potential GDP), it abstracts from cyclical/temporary factors, although there are large uncertainties around such cyclically-adjusted estimates;

- It is forward-looking, so for instance it accounts for projected trends in interest rates and growth;

Stabilisation of government debt ratios can be thought of as a sort of 'lower bound' on fiscal sustainability and the use of initial debt ratios as targets has a limited impact on the fiscal pressure indicator. Indeed, allowing debt ratios to stabilise at higher levels would leave the projected evolution of the fiscal pressure indicator little changed as this evolution depends primarily on initial structural fiscal balances and projected trends in expenditure.

28. As demonstrated by the stylised debt trajectories shown previously, the long-run fiscal challenge confronting OECD governments occurs in spite of favourable $r-g$ conditions and is attributable to upward pressure on expenditure due to population ageing and the rising relative price of services. Under a 'business-as-usual' hypothesis, in which no major reforms to government programmes are undertaken, public expenditure is projected to rise substantially in most countries (see Box 1 and references therein for methodological details on how public expenditure are projected):

- Public health and long-term care expenditure is projected to increase by 2.2 percentage points of GDP in the median country between 2021 and 2060 (Figure 13, Panel A). These projections are based on a pre-pandemic spending baseline, so any permanent increase in health spending in response to experience with COVID-19 (for instance to build more spare capacity in intensive care units or raise pay levels for workers in public care homes) would come in addition.

- Public pension expenditure is projected to increase by 2.8 percentage points of GDP in the median country between 2021 and 2060, but cross-country variability is much higher than in the case of health expenditure projections (Figure 13, Panel A). Countries that have legislated increases in statutory retirement ages, and especially those that have linked future increases to gains in life expectancy, such as Estonia, the Netherlands and Portugal, tend to have lower projected increases in public pension expenditure, whereas countries with particularly unfavourable demographics, such as Japan, tend to have higher projected spending increases.

- Other primary expenditures are projected to rise by $1 \frac{1}{2}$ percentage points of GDP in the median country between 2021 and 2060 (Figure 13, Panel A). This projection excludes potential new sources of expenditure pressure, such as climate change adaptation. 
Figure 13. Potential future fiscal pressure to keep public debt ratio at current level in the baseline scenario

A. Change in fiscal pressure between 2021 and $2060 \%$ pts of potential GDP

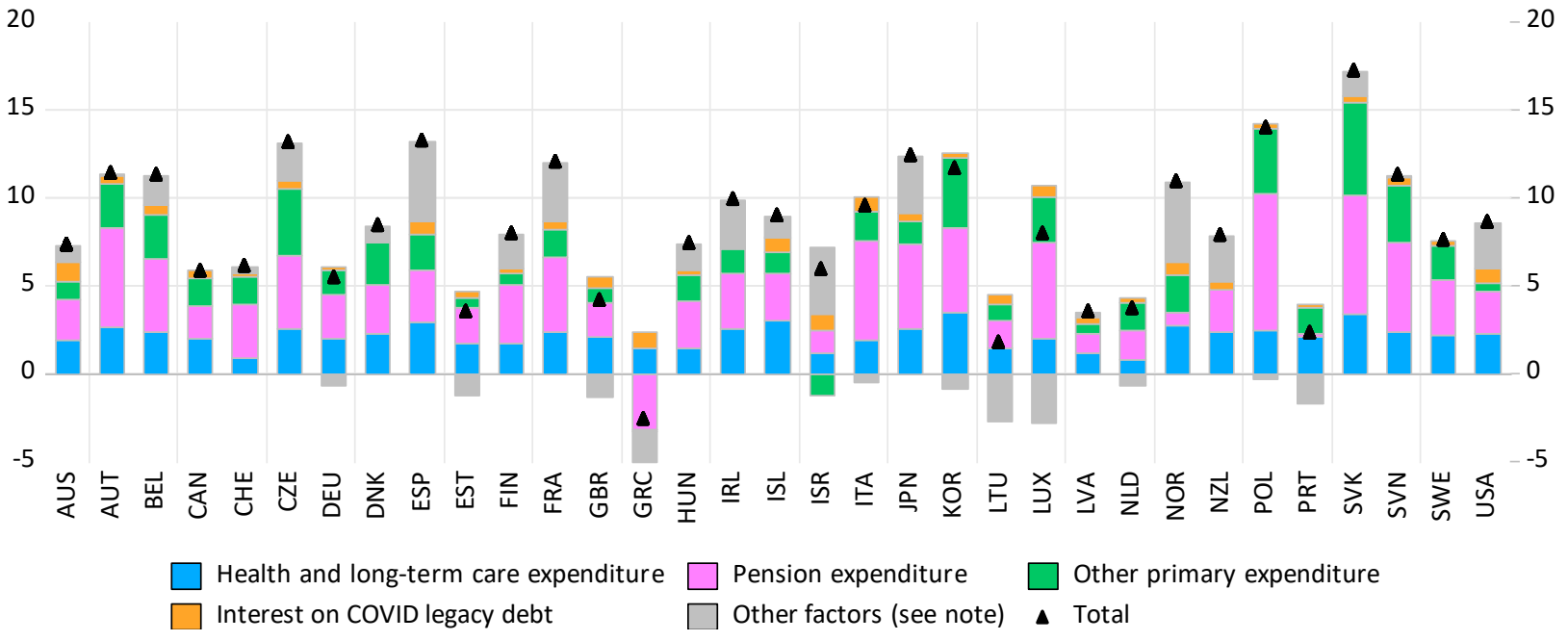

B. Fiscal pressure in 2021 and $2060, \%$ of potential GDP

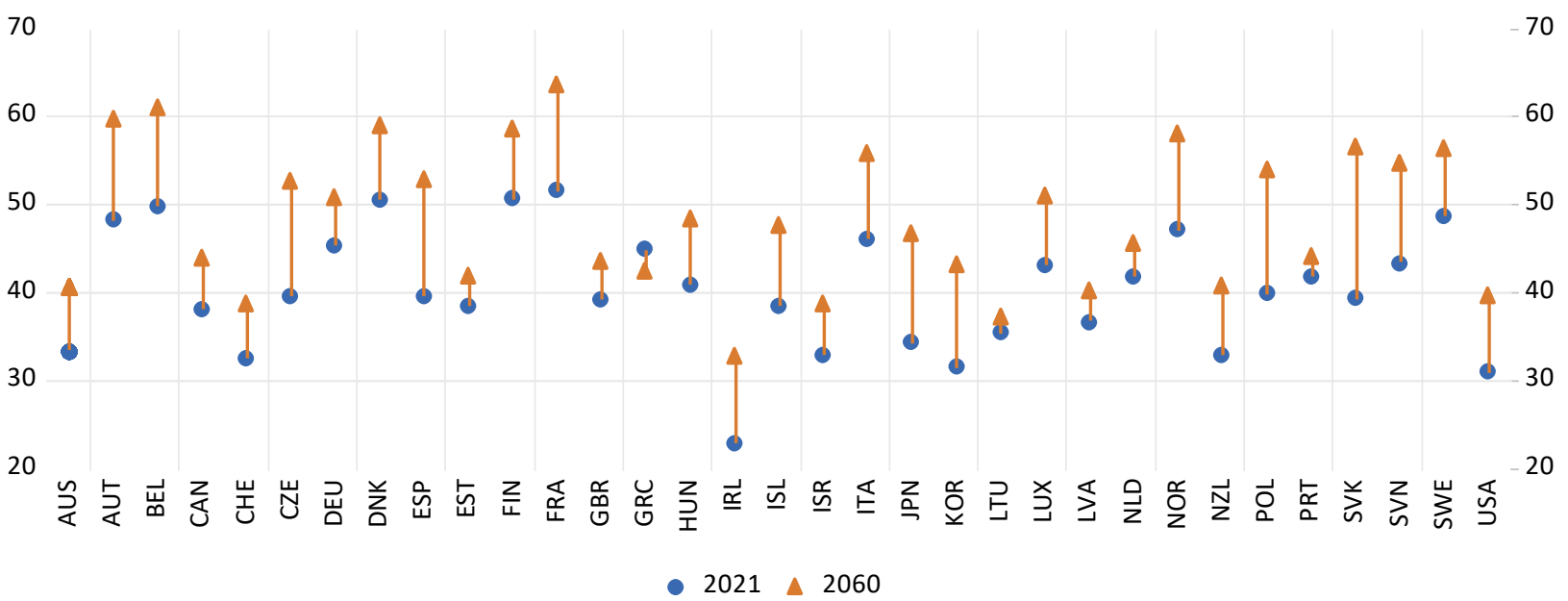

Note: The charts show how the ratio of structural primary revenue to GDP must evolve between 2021 and 2060 to keep the gross debt-to-GDP ratio stable near its current value over the projection period (which also implies a stable net debt-to-GDP ratio given the assumption that government financial assets remain stable as a share of GDP). The underlying projected growth rates, interest rates, etc., are from the baseline long-term scenario presented in section 2. Expenditure on temporary support programmes related to the COVID-19 pandemic is assumed to taper off quickly. In Panel A, the necessary change in structural primary revenue is decomposed into specific spending categories. The component "Interest on COVID legacy debt" approximates the permanent increase in interest payments due to the COVID-related increase in public debt between 2019 and 2022. The component 'Other factors' captures anything that affects debt dynamics other than the explicit expenditure components (it mostly reflects the correction of any disequilibrium between the initial structural primary balance and the one that would stabilise the debt ratio). In Panel B, blue dots show structural primary revenue in 2021 and arrows show the change during the 2021-to2060 period. See Box 1 for more details.

- The additional debt service on the increase in public debt due to the COVID-19 pandemic - here approximated by the increase in gross government debt between 2019 and 2022 - adds only about $1 / 2$ percentage point of GDP to long-run fiscal pressure in the median country. Emergency fiscal transfers during the COVID period contribute little to long-run fiscal pressure because they are temporary. Their permanent component is the flow of interest payments on the associated stock of 
additional debt, assuming that it is permanently rolled over, which is the case here because of the assumption that the government debt-to-GDP ratio is stabilised at its 2022 level.

In addition to projected expenditure increases in specific categories, the fiscal pressure indicator also includes in the 'other factors' component any adjustment to the initial fiscal position that must occur to stabilise the public debt ratio. This component is positive when the initial structural primary balance would imply a rising debt ratio over time, and vice versa, conditional on projected paths for growth and interest rates.

29. Except in Greece, where a massive fiscal consolidation effort has already taken place since the Great Recession, all OECD governments would need to raise taxes in this scenario to prevent gross government debt ratios from rising over time (Figure 13, Panel A). The median country would need to increase structural primary revenue by nearly 8 percentage points of GDP between 2021 and 2060, but the effort would exceed 10 percentage points in 11 countries. Greece's favourable outcome is due in part to declining public pension expenditure following recent reforms, and in part to its relatively high initial structural primary balance, as stipulated in the Stability Programme. Projected increases in fiscal pressure by 2060 are somewhat higher than in the previous version of this exercise, by about 1.3 percentage point for the median country, but revisions are difficult to interpret because of important methodological changes (Box 2).

30. The results of this section do not imply that taxes will, or even should, rise in the future. The fiscal pressure indicator is simply a metric serving to quantify and illustrate the fiscal challenge facing OECD governments. Raising taxes is only one of many possible avenues to meet this challenge. While this strategy appears feasible in some countries where tax levels are relatively low, in other countries it may present a substantial challenge. In Belgium, Denmark, Finland and France, for instance, structural primary revenue is already around $50 \%$ of GDP (Figure 13, Panel B). Pushing mainstream taxes on incomes or consumption further up, even by only a few percentage points of GDP, may be politically difficult and fiscally counter-productive if it means reaching the downward-sloping segment of the Laffer curve (Akgun, Cournède and Fournier, 2017[17]). Lundberg $\left(2017_{[18]}\right)$ identifies five OECD countries where top effective marginal tax rates (accounting for income, payroll and consumption taxes) are already beyond revenuemaximizing levels (Austria, Belgium, Denmark, Finland and Sweden). Thus, if taxes are to rise, it might be necessary to look to other bases, such as housing, capital gains, inheritance or wealth. Recent international efforts to establish a minimum global corporate tax could also enable more revenue to be raised from corporate taxes.

31. Another avenue would be reforming health and pension systems to increase efficiency and prevent expenditure from rising as much as projected in this stylised exercise. Additional debt finance could also be undertaken in some countries (see next subsection). No strategy is inherently superior to the others and considerations missing from the framework, such as distributional issues, should also figure in the decision process. If the choice is made to meet the fiscal pressure challenge by raising taxes, then consideration needs to be given to using tax instruments that are least harmful to growth and most friendly to income distribution. Rouzet et al. (2019[19]) discuss the policy options available to alleviate the fiscal pressures associated with ageing in more depth. 


\section{Box 2. Revisions to projected increases in fiscal pressure since 2018 study}

The fiscal pressure indicator shown in Figure 13 was first reported in Guillemette and Turner $\left(2018_{[1]}\right)$. There have since been methodological improvements to the underlying fiscal projections that can explain substantial revisions to projected long-term fiscal pressure in many countries.

\section{Health and long-term care expenditure}

Projected increases in health expenditure through 2060 are generally lower in the current version than in the previous one, by about $2 \frac{1}{2}$ percentage points of GDP in the median OECD country. The main reason is a change of approach to projecting the Baumol effect (i.e. rising relative price) of health and long-term care services. Previously, the health and long-term care services price index was assumed to increase by 1.3 percentage point more annually than the GDP deflator, an assumption calibrated on the average experience of 34 OECD countries over the 1995-to-2015 period. This same assumption was common to all countries and was arguably 'pessimistic'. The revised approach endogenises the Baumol effect to each country's projected labour productivity growth. Given fairly weak projected labour productivity growth in most countries relative to historical norms, the new approach generally results in a weaker Baumol effect.

\section{Pension expenditure}

Projected increases in public pension expenditure through 2060 are generally higher in the current version than in the previous one, by about 2 percentage points of GDP in the median OECD country. Previous pension expenditure projections were exogenous, sourced from the European Commission's Ageing Report for EU countries and Standard and Poor's (2016[20] $)$ for other countries. The revised approach endogenises pension expenditure projection, using a framework similar to the European Commission's, except that the average pension benefit ratio (i.e. ratio of average pension benefit to average wage) is assumed to remain stable over the long run, save for a few countries where there have been significant reforms (see Box 1). By contrast, average pension benefit ratios generally decline throughout the projection period in the European Commission projections. See section 3.3 in Guillemette and Turner $\left(2018_{[1]}\right)$ for a more detailed explanation of this methodological choice.

\section{Other components and total}

Projected increases in other primary expenditure (i.e. excluding health, long-term care and pension) through 2060 have not changed substantially from the 2018 study in the median country, although there can be larger differences in individual countries.

The new component 'Interest on COVID legacy debt' mainly picks up the fact that in the current version, public debt ratios are generally being stabilised at higher levels than in the 2018 version, adding about $1 / 2$ percentage point of GDP to fiscal pressure in the median country in the form of higher interest payments.

The size of the 'Other factors' component has also generally increased relative to the 2018 study, by about $1 / 2$ percentage point of GDP in the median country. This can be due to weaker initial structural fiscal positions, higher interest rate trajectories through 2060 without corresponding increases in growth rates, or a combination of these two factors.

Overall, in the median OECD country, fiscal pressure is projected to increase by 1.3 percentage point of GDP more by 2060 in this study than in the 2018 version. 


\subsection{Historically low interest rates make additional debt finance feasible in many countries}

32. If financing conditions remain favourable, as assumed in the baseline scenario, countries with relatively low initial public debt ratios could finance some of the projected increases in expenditure with debt. Despite generally rising public debt ratios, net interest payments have been declining in OECD countries since the mid-1990s, thanks to declining interest rates. In the median OECD country, net interest payments currently amount to about $1 \%$ of GDP, similar to just before the 2009 global financial crisis and otherwise not seen since the late 1970s (Figure 14). In the baseline scenario, owing to the assumed modest increases in interest rates, median net interest payments increase slightly to reach $1 \frac{11 / 4}{\text { per cent of }}$ GDP by 2060 , still low by historical norms.

\section{Figure 14. Net interest payments remain low through 2060 in the baseline scenario}

Median and interquartile range for OECD countries, $\%$ of GDP

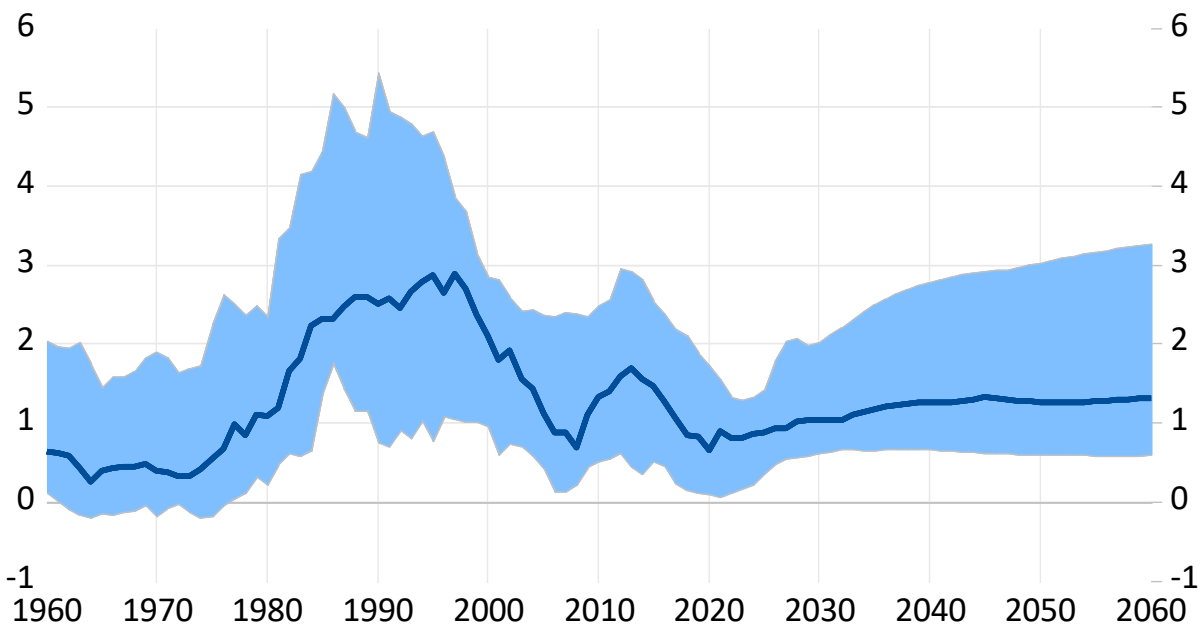

Source: OECD Economic Outlook No. 109 for history and baseline long-run scenario for projections.

33. Looking at the OECD median hides substantial variation across OECD countries, however, both in terms of current levels as well as how they are projected to evolve in the baseline scenario. Already in 2021, net interest payments are relatively high (more than $2 \%$ of GDP) in Greece, Hungary, Iceland, Italy, Portugal and the United States (Figure 15). By 2060, Iceland has refinanced high-interest legacy debt at lower interest rates, pushing down net interest payments somewhat. On the other hand, by then, net interest payments exceed 3\% of GDP in several countries, a consequence of relatively high government debt ratios as well as the baseline assumption of moderate increases in interest rates. The increases in net interest payments are especially large in Greece, where newly-issued debt at market interest rates gradually replaces debt with official creditors financed at non-market interest rates, and Japan, where the baseline assumption that the neutral interest rate converges toward the potential growth rate represents a particularly large shock. Net interest payments of more than 3\% of GDP is toward the upper range of historical variation, indicating greater vulnerability to a larger increase in interest rates (that would not be matched by higher growth) than assumed in the baseline scenario. 
Figure 15. Net interest payments are projected to increase moderately in most countries

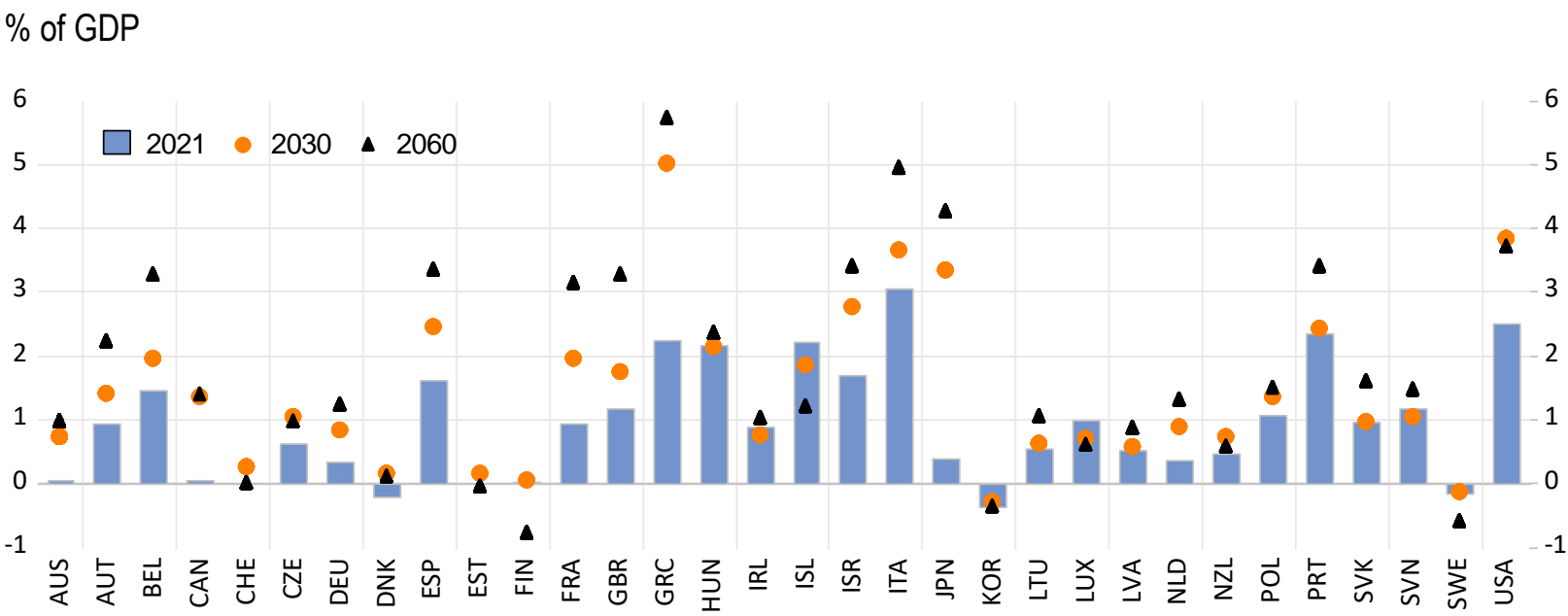

Note: Norway is not shown in this chart given its high level of government financial assets. The figure for Greece takes into account the share of public debt with official creditors financed at non-market interest rates.

34. For all other countries, low net interest payments over the full projection horizon suggest the possibility of financing future increases in expenditure with additional borrowing. How much additional borrowing might be sustainable is difficult to say, especially when considering that much of the ongoing increases in public debt are being absorbed by central banks. The potential for closer coordination in future between fiscal and monetary policies is not explicitly taken into account in this paper's analysis.

35. With higher public debt would come risks, however. Even if the $r<g$ condition remained met, guaranteeing that the public debt ratio would eventually stabilise, it would almost certainly do so at a level too high for comfort in terms of rollover risks. Indeed, $r<g$ does not imply that a sovereign debt crisis cannot occur. Historically, differentials were no higher prior to sovereign defaults than in normal times (Mauro and Zhou, 2020[21]). Marginal government borrowing costs often rise abruptly and sharply just prior to default. Another trade-off of high public debt is that it tends to hinder the role of fiscal policy as a countercyclical stabilisation tool (Larch, Orseau and Van der Wielan, 2020[22]). Fiscal policy may increasingly be called on to play such a role in the years ahead given the limited room for monetary policy rates to fall further and concerns around sustained use of non-conventional monetary policy interventions. For these reasons, absorbing future fiscal pressure with additional borrowing is a strategy that could postpone, but probably not avoid, the need for policy reforms.

\section{Alternative scenarios illustrate interest rate risks as well as the potential fiscal dividends from structural reforms}

36. There are both positive and negative risks around the baseline fiscal assessment presented previously. This section looks, in turn, at interest-rate risks and at the potential impact of higher growth, either from faster technical progress or higher employment rates, on future fiscal pressure.

\subsection{Sensitivity to interest rates}

37. Given large uncertainties around the future path of interest rates, two alternative scenarios consider the impact of lower or higher rates on government debt than in the baseline scenario. The interest rate shocks are implemented in the model by arbitrarily subtracting (positive risk) or adding (negative risk) one percentage point to equilibrium short-term neutral interest rates in all countries. In the Laubach and 
Williams $\left(2003_{[10]}\right)$ framework introduced previously, the natural real interest rate is equal to the economy's trend growth rate plus an unobserved stochastic component that captures other influences. The shocks assumed here conceptually occur in this unobserved component and amount to a little over three times the quarterly standard deviation of this component estimated for the OECD area over the period 1971 to 2017 (Rachel and Summers, 2019[23]). The shocks are rapidly reflected in short and long-term interest rates, and more gradually in implicit average interest rates on government debt depending on countryspecific debt maturity structures, which are calibrated on the latest available information and assumed to remain unchanged over the projection period. Lower/higher interest rates boost/depress growth slightly via their impact on the user cost of capital and investment, but this is a second-order effect as concerns fiscal outcomes.

38. The first-order effects of interest rate shocks are on interest payments on government liabilities and interest receipts on government financial assets, leading to differentiated impacts across countries depending on net government debt positions. In countries with net liability positions, higher interest rates than in the baseline scenario add to projected fiscal pressure, by as much as 1 to $1 \frac{1}{2}$ percentage points of GDP in those countries with the highest net debt positions, such as Greece, Italy, Japan and Portugal (Figures 16 and 17). Some of these countries already have high fiscal pressure levels in the baseline scenario and may find it difficult to deal with further fiscal pressure given political-economy constraints. Conversely, because the model relates the return on government financial assets to global interest rates, higher interest rates alleviate future fiscal pressure slightly in countries with net financial asset positions. The findings are reversed in the scenario with lower interest rates, but the countries most affected are the same.

\section{Figure 16. One percentage point lower/higher interest rates than in the baseline scenario moderately impacts projected fiscal pressure, except in high-debt countries}

Fiscal pressure in $2060, \%$ of potential GDP

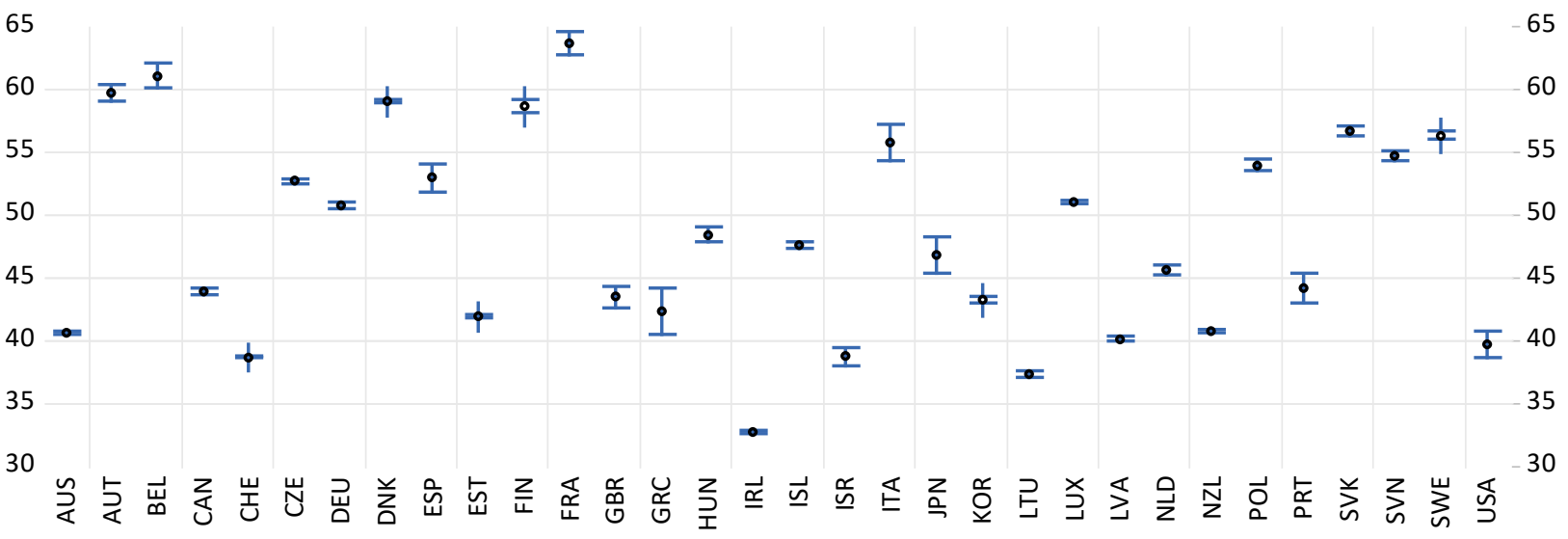

Note: The dot shows projected structural primary revenue in 2060 in the baseline scenario and the vertical line shows the variation between the scenario with one percentage point lower equilibrium interest rates and one percentage point higher. Vertical half-lines outside of the interval (e.g. Korea) indicate that the lower interest rate scenario leads to higher fiscal pressure, and vice-versa for the higher interest rate scenario. This happens in countries with more government financial assets than debt (i.e. negative net debt). Public debt-to-GDP ratios are kept constant at initial values in the alternative scenarios as per the model's fiscal adjustment mechanism (see Box 1). The figure for Greece takes into account the share of public debt with official creditors financed at non-market interest rates. Norway is not shown on the chart because its large net asset position yields substantially more revenue in this scenario, but in reality much of the financial assets held by its sovereign wealth funds are publicly-traded equities whose returns do not necessarily rise with safe interest rates.

39. Sensitivity of net interest payments to initial net debt positions can be appreciated by considering the impact of higher interest rates on net interest payments in 2040 (once higher interest rates have mostly 
passed through to the average implicit interest rate on debt) together with net government debt ratios. Higher net government debt levels magnify the impact of higher interest rates (Figure 17). Net interest payments increase by one percentage point of GDP or more in this risk scenario relative to the baseline one in several countries, including Italy, Japan, Greece and the United States. More generally, countries toward the top right-hand corner of Figure 17 may be most vulnerable to funding stress in a scenario where interest rates go up substantially.

40. Besides addressing sources of vulnerabilities that could trigger financial-market stress, notably rapid debt accumulation in the non-bank corporate sectors of many economies and foreign-currency borrowing in emerging-market economies (Kose et al., 2020[24]), fiscal authorities can reduce the eventual impact of an interest-rate surprise by taking advantage of favourable long-term financing conditions now to extend government debt maturities, in particular Italy (Maravalle and Rawdanowicz, 2018[25]). Extending debt maturities is one of the five elements of the more resilient fiscal architecture put forward by Orszag, Rubin and Stiglitz (2021 [26]). Countries with already high tax and public debt levels should also find ways to alleviate future expenditure pressure and boost confidence in their long-term prospects. One of the best ways of doing so might be through reforms to labour market policies and public pension programmes that seek to raise employment rates and extend working lives, and many countries are already going in this direction. The next sub-section illustrates the potential fiscal gains from such a strategy.

\section{Figure 17. The impact of higher interest rates on net interest payments depends on net debt ratios}

Net government debt and net interest payments in 2040, percent of GDP

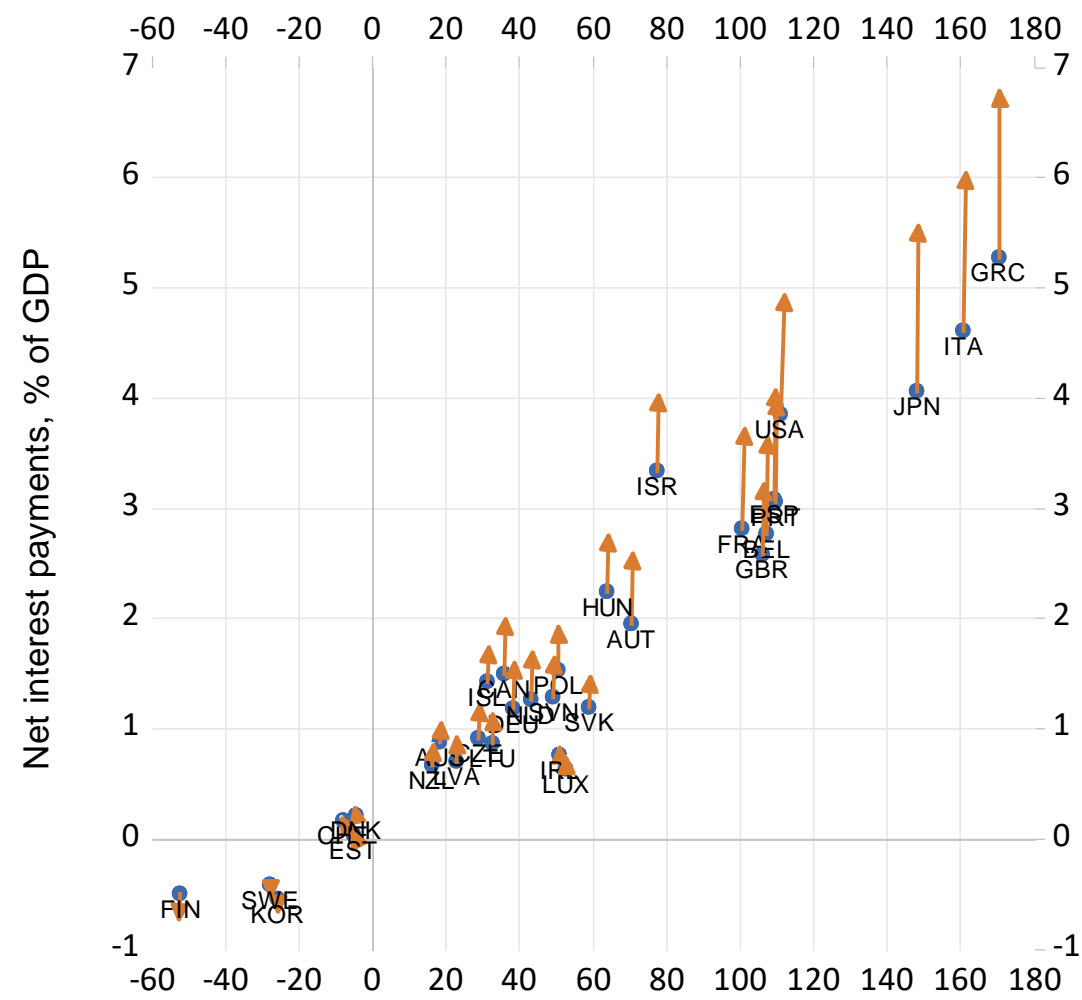

Net government debt, \% of GDP

Note: The blue dots relate net government debt in 2040 to net interest payments in that year in the baseline scenario. The yellow arrows show the impact of the one-percentage point increase in interest rates on net interest payments in 2040, net government debt being essentially unchanged from the baseline scenario as per the model's fiscal rule. The figure for Greece takes into account the share of public debt with official creditors financed at non-market interest rates. 


\subsection{Fiscal dividends from structural reforms}

41. The alternative scenarios previously described in section 3 can be used to illustrate the fiscal dividends associated with growth-boosting structural reforms.

42. Higher labour efficiency growth (section 3.1) yields negligible fiscal dividends given the framework and assumptions used in the present exercise, for several reasons.

- It is assumed that the equilibrium real interest rate reacts one-for-one with an economy's potential growth rate, so there is no gain in terms of a lower $r-g$ from faster growth. ${ }^{12}$ Under the alternative assumption that the real interest rate reacted less than one-for-one with potential growth, higher labour efficiency growth would yield some fiscal dividends.

- Part of the secular increase in health care costs is assumed to be due to the Baumol effect, i.e. the tendency for the relative price of labour-intensive services to rise over time because of slower productivity growth in services. Higher trend labour efficiency growth actually magnifies the Baumol effect, leading to higher health spending as a share of GDP.

- Given the baseline assumption that the average pension benefit grows at the same rate as the average wage over the long run, higher labour efficiency growth does not lower public pension spending as a share of GDP. Assuming less than full wage indexation of pension benefits would give rise to a fiscal dividend, but would also imply that pensioners would lose purchasing power over time relative to wage earners.

- Non-health and non-pension primary expenditure do not decline as a share of GDP with higher trend labour efficiency growth, again because of the assumption that public sector wages and benefits follow total-economy labour productivity over the long run (see Box 1). This assumption is a simplification, however, and there could be some modest fiscal benefits from this component.

In an economy where public sector wages and benefit rates from transfer programmes tend to stay in line with the average wage over the long run, either from explicit indexation or ad-hoc adjustments, the general point that higher trend labour efficiency growth does not provide a fiscal elixir is an important one. At the same time, in reality some modest fiscal benefits - assumed away by the stylised assumptions of the baseline scenario - would likely materialise, especially in the short run. Productivity gains in the public sector itself, especially in health care, could reduce the Baumol effect and help to relieve fiscal pressure. Higher productivity growth could also make it easier to accommodate any given increase in fiscal pressure, because it would make it easier to ensure that post-tax wages still rise.

43. On the contrary, structural reforms that raise employment rates are associated with substantial fiscal dividends. In the context of slowing global population growth and even declining population in many countries, combined with population ageing everywhere, labour market reforms that would raise employment and encourage longer working lives appear particularly desirable. In addition to reducing fiscal pressure, such reforms can help women and disadvantaged groups gain employment. ${ }^{13}$

44. Keeping with the fiscal pressure indicator used previously - structural primary revenue required to keep the gross public debt ratio stable at its initial level through 2060 - the fiscal dividend associated with

\footnotetext{
${ }^{12}$ A robust prediction of most workhorse macroeconomic models is that the natural interest rate should vary together with an economy's expected future trend growth rate. One example is the Laubach and Williams (2003 $\left.{ }_{[10]}\right)$ model, in which the natural rate is equal to the economy's trend growth rate plus an unobserved stochastic component that captures other influences. It implies that permanent shocks to $g$ would be fully reflected in $r$, all else equal.

13 See also OECD $\left(2020_{[34]}\right)$ for stylized scenarios illustrating the potential long-run gains in GDP per capita from reducing current gaps between male and female employment rates and increasing employment rates for older age groups.
} 
labour market reforms can be expressed as the impact of the reforms on this measure relative to the baseline scenario.

- The labour market reform package described in section 3.2 lowers fiscal pressure in 2060 by $13 / 4$ percentage points of GDP in the median OECD country, a fifth of the projected baseline increase (Figure 18, orange dots). In countries with the most to gain from labour market reforms, the potential reduction in fiscal pressure reaches 4-5 percentage points of GDP. When comparing to the baseline scenario (see Figure 13 above), labour market reforms thus have the potential to offset a substantial portion of the projected increases in fiscal pressure, notably in Belgium, France and Italy. However, while the fiscal costs of raising expenditure on ALMP and family benefits are taken into account in these calculations, increases in maternity leave and tax wedge reductions are assumed to be fiscally neutral. The tax wedge reductions, which account for the bulk of fiscal dividends, should be understood as shifts toward less-distorting forms of taxation, as recommended in previous OECD work (Johansson, 2016[27]; Akgun, Cournède and Fournier, $\left.2017_{[17]}\right)$. Previous work indeed found that, for a constant government size, shifting taxes away from labour and toward consumption and property typically raises real output per capita. However, such a shift must be designed carefully to avoid deleterious distributional impacts.

\section{Figure 18. Labour market reforms would help alleviate future fiscal pressure}

Fiscal pressure in $2060, \%$ of potential GDP

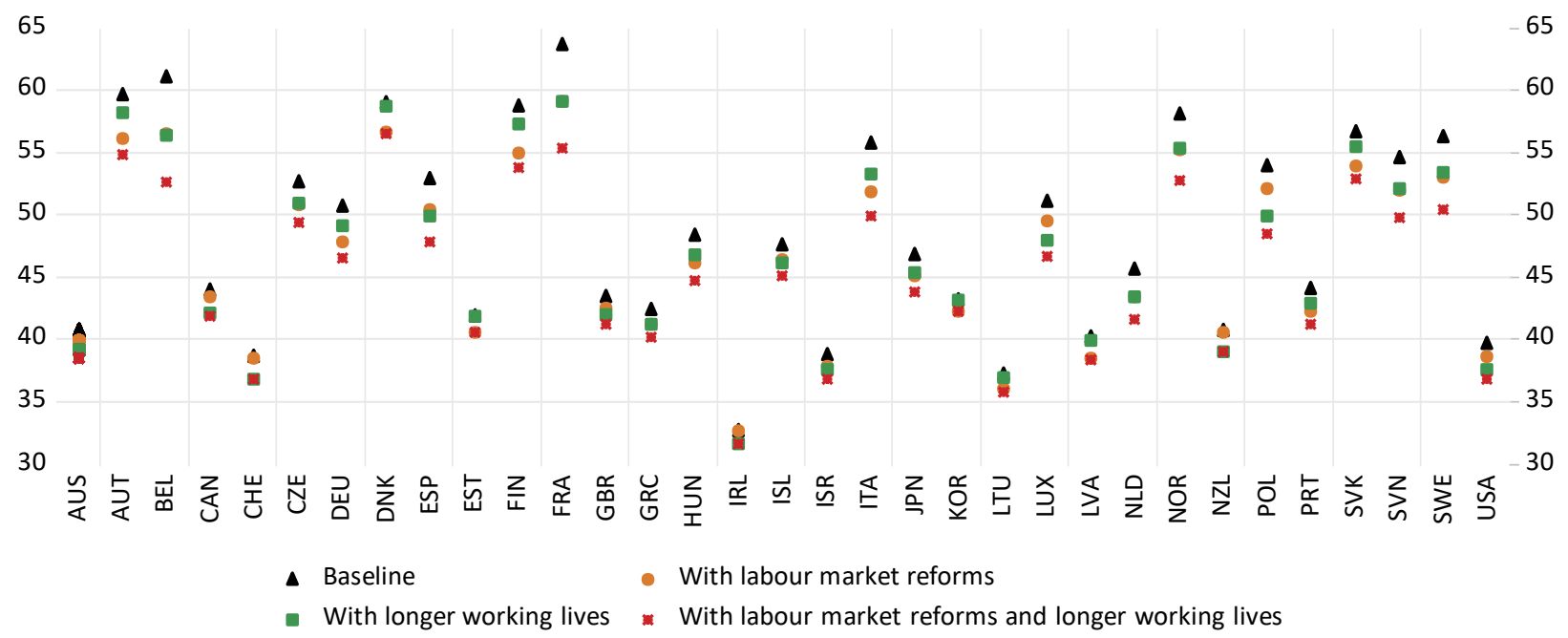

Note: The black triangles show projected structural primary revenue in 2060 in the baseline scenario. The orange dots show projected structural primary revenue in 2060 in the alternative scenario with a package of labour market reforms (see section 3.2). The green squares show projected structural primary revenue in 2060 in the alternative scenario where reforms would close any initial shortfall between average effective and normal statutory retirement ages for men and women, as well as keep future increases in average effective retirement ages equal to two thirds of projected gains in life expectancy (see section 3.3). When early pension withdrawal is possible (with penalty), the initial shortfall is calculated as the difference between the average effective and the early retirement age, if it is negative. The red stars combine the two alternative scenarios.

- In the alternative scenario where initial gaps between average effective and statutory normal retirement ages are closed and average effective retirement ages keep rising in line with two thirds of future gains in life expectancy, fiscal pressure in 2060 declines by $11 \frac{1}{2}$ percentage points of GDP in the median OECD country, but by 4-5 percentage points of GDP in some European countries (Figure 18, green squares). ${ }^{14}$ These tend to be the countries where fiscal pressure is projected to

\footnotetext{
${ }^{14}$ Some countries appear to benefit less from this scenario simply because they have already legislated increases in statutory retirement ages and such reforms are included in the baseline scenario. Among such countries, fiscal
} 
rise the most in the baseline scenario. Linking future increases in statutory retirement ages to gains in life expectancy is consistent with the Orszag, Rubin and Stiglitz (2021 [26]) prescription to index long-term fiscal programmes to their underlying drivers so as to reduce fiscal uncertainty.

- A scenario that combines labour market policy reforms (from section 3.2) with increases in average effective retirement ages (from section 3.3) illustrates the potential fiscal dividends of an ambitious reform package geared simultaneously toward boosting employment rates and extending working lives. Fiscal pressure in 2060 is substantially lower than in the baseline scenario -3 percentage points of GDP lower for the median country (Figure 18, red stars). This represents a halving of the projected median increase in fiscal pressure between 2021 and 2060 in the baseline scenario (of nearly 8 percentage points of GDP). In some cases, fiscal pressure could remain around today's levels, notably in Lithuania, Portugal and the Netherlands (Figure 19, Panel A). The fiscal dividends are mostly due to longer working lives reducing future pension and other primary expenditure as a share of GDP, with much lower impact on health expenditure (Figure 19, Panel B). Some countries, such as Ireland and Korea, benefit less from the simulated reform package, but this is mostly because they already have high employment rates, have already legislated increases in statutory retirement ages and score relatively highly on many labour market policy indicators, so the implied policy adjustments are less sizeable.

pressure is estimated to be $3 / 4$ percentage point of GDP lower by 2060 in the median country relative to a scenario where statutory retirement ages remain unchanged. Again, countries that have legislated a link between statutory retirement ages and life expectancy benefit the most, with reductions in fiscal pressure of as much as 3-31/2 percentage points of GDP in Denmark and Finland relative to a scenario where statutory retirement ages remain unchanged. 
Figure 19. Potential future fiscal pressure to keep public debt ratio at current level with reforms to labour market and retirement policies

A. Change in fiscal pressure between 2021 and $2060 \%$ pts of potential GDP

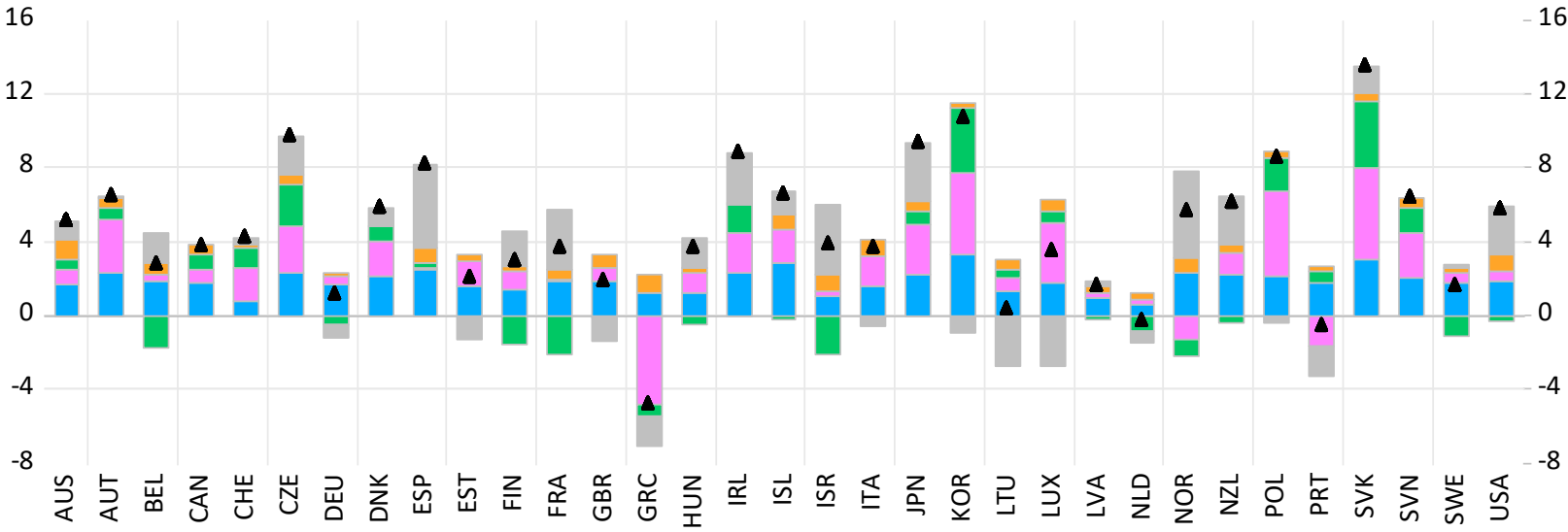

B. Difference from baseline scenario, \% pts of potential GDP

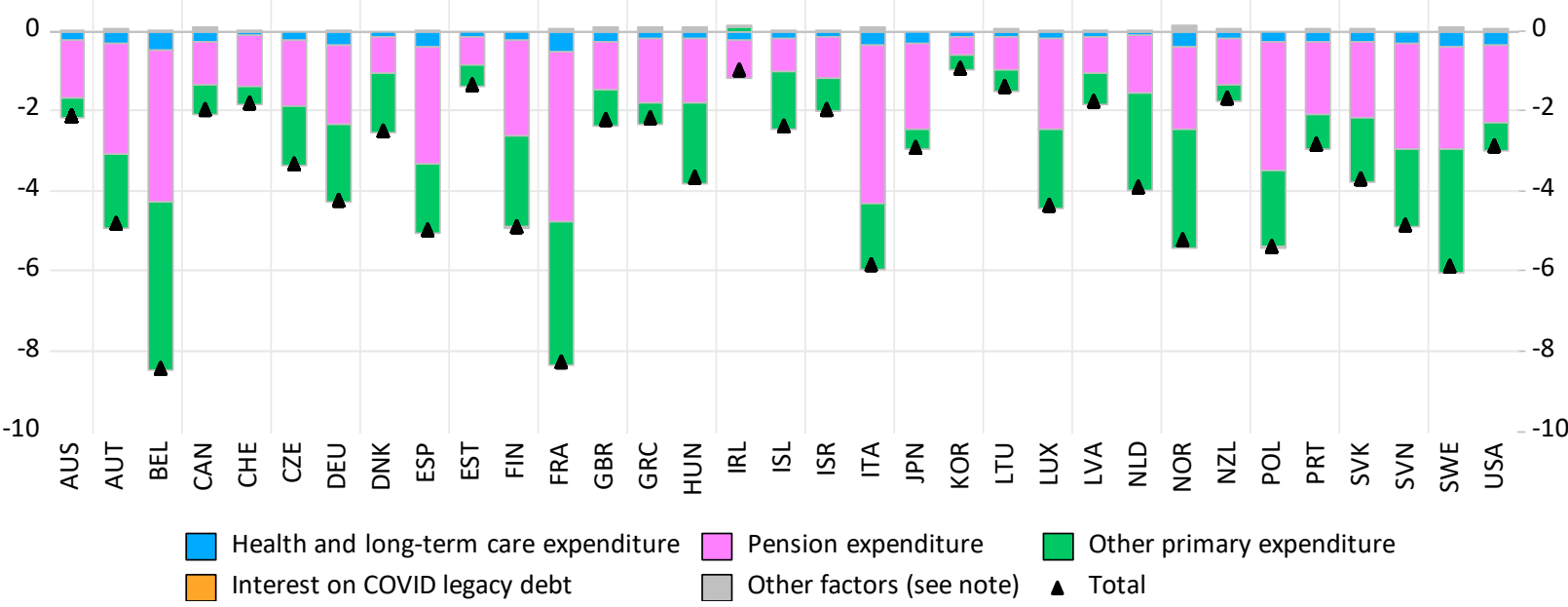

Note: Panel A shows how the ratio of structural primary revenue to GDP must evolve between 2021 and 2060 to keep the gross debt-to-GDP ratio stable near its current value over the projection period (which also implies a stable net debt-to-GDP ratio given the assumption that government financial assets remain stable as a share of GDP). The underlying projected growth rates, interest rates, etc., are from an ambitious reform scenario combining the labour market policy reforms (from section 3.2) with increases in average effective retirement ages (from section 3.3). Expenditure on temporary support programmes related to the COVID-19 pandemic is assumed to taper off quickly. The necessary change in structural primary revenue is decomposed into specific spending categories. The component "Interest on COVID legacy debt" approximates the permanent increase in interest payments due to the COVID-related increase in public debt between 2019 and 2022 . The component 'Other factors' captures anything that affects debt dynamics other than the explicit expenditure components (it mostly reflects the correction of any disequilibrium between the initial structural primary balance and the one that would stabilise the debt ratio). Panel B shows the difference between Panel $A$ and the baseline change in fiscal pressure shown in Figure 13, Panel A. 


\section{References}

Akgun, O., B. Cournède and J. Fournier (2017), "The effects of the tax mix on inequality and growth", OECD Economics Department Working Papers, No. 1447, OECD Publishing, Paris, https://doi.org/10.1787/c57eaa14-en.

Arriola, C. et al. (2020), "Efficiency and risks in global value chains in the context of COVID-19", OECD Economics Department Working Papers, No. 1637, OECD Publishing, Paris, https://doi.org/10.1787/3e4b7ecf-en.

Blanchard, O., A. Leandro and J. Zettelmeyer (2021), "Redesigning EU fiscal rules: From rules to standards", Economic Policy, Vol. eiab003, https://doi.org/10.1093/epolic/eiab003.

Cavalleri, M. and Y. Guillemette (2017), "A revised approach to trend employment projections in long-term scenarios", OECD Economics Department Working Papers, No. 1384, OECD Publishing, Paris, https://dx.doi.org/10.1787/075f0153-en.

Chalaux, T. and Y. Guillemette (2019), "The OECD potential output estimation methodology", OECD Economics Department Working Papers, No. 1563, OECD Publishing, Paris, https://doi.org/10.1787/4357c723-en.

Dang, T., P. Antolín and H. Oxley (2001), "Fiscal Implications of Ageing: Projections of AgeRelated Spending", OECD Economics Department Working Papers, No. 305, OECD Publishing, Paris, https://doi.org/10.1787/503643006287.

De la Maisonneuve, C. and J. Oliveira Martins (2013), "A Projection Method for Public Health and Long-Term Care Expenditures", OECD Economics Department Working Papers, No. 1048, OECD Publishing, Paris, https://dx.doi.org/10.1787/5k44v53w5w47-en.

Égert, B. and P. Gal (2017), "The quantification of structural reforms in OECD countries: A new framework", OECD Economics Department Working Papers, No. 1354, OECD Publishing, Paris, https://dx.doi.org/10.1787/2d887027-en.

European Commission (2018), "The 2018 Ageing Report: Economic and Budgetary Projections for the EU Member States (2016-2070)", Institutional Paper, No. 079, European Commission, Brussels.

Gal, P. and A. Theising (2015), "The macroeconomic impact of structural policies on labour market outcomes in OECD countries: A reassessment", OECD Economics Department Working Papers, No. 1271, OECD Publishing, Paris, https://dx.doi.org/10.1787/5jrqc6t8ktjfen. 
Guillemette, Y. (2019), "Recent improvements to the public finance block of the OECD's longterm global model", OECD Economics Department Working Papers, No. 1581, OECD Publishing, Paris, https://doi.org/10.1787/4f07fb8d-en.

Guillemette, Y., A. de Mauro and D. Turner (2018), "Saving, Investment, Capital Stock and Current Account Projections in Long-Term Scenarios", OECD Economics Department Working Papers, No. 1461, OECD Publishing, Paris, https://doi.org/10.1787/aa519fc9-en.

Guillemette, Y. et al. (2017), "A revised approach to productivity convergence in long-term scenarios", OECD Economics Department Working Papers, No. 1385, OECD Publishing, Paris, https://dx.doi.org/10.1787/0b8947e3-en.

Guillemette, Y. and D. Turner (2018), "The Long View: Scenarios for the World Economy to 2060", OECD Economic Policy Papers, No. 22, OECD Publishing, Paris, https://doi.org/10.1787/b4f4e03e-en.

Guillemette, Y. and D. Turner (2017), "The fiscal projection framework in long-term scenarios", OECD Economics Department Working Papers, No. 1440, OECD Publishing, Paris, https://dx.doi.org/10.1787/8eddfa18-en.

Johansson, A. (2016), "Public Finance, Economic Growth and Inequality: A Survey of the Evidence", OECD Economics Department Working Papers, No. 1346, OECD Publishing, Paris, https://doi.org/10.1787/094bdaa5-en.

Johansson, Å. et al. (2013), "Long-Term Growth Scenarios", OECD Economics Department Working Papers, No. 1000, OECD Publishing, Paris, https://dx.doi.org/10.1787/5k4ddxpr2fmren.

Jones, C. (2015), "The Facts of Economic Growth", NBER Working Papers, No. 21142, National Bureau of Economic Research.

Kilic Celik, S., A. Kose and F. Ohnsorge (2020), "Subdued Potential Growth: Sources and Remedies”, Policy Research Working Paper, No. 9177, World Bank, Washington, D.C., http://documents.worldbank.org/curated/en/976181583843503040/Subdued-PotentialGrowth-Sources-and-Remedies.

Kose, M. et al. (2020), Global Waves of Debt: Causes and Consequences, World Bank, Washington, D.C.

Larch, M., E. Orseau and W. Van der Wielan (2020), "Do EU Fiscal Rules Support or Hinder Counter-Cyclical Fiscal Policy?", CESifo Working Papers, No. 8659, https://www.cesifo.org/DocDL/cesifo1 wp8659.pdf.

Laubach, T. and J. Williams (2003), "Measuring the Natural Rate of Interest", Review of Economics and Statistics, Vol. 85/4, pp. 1063-70.

Lundberg, J. (2017), “The Laffer Curve for High Incomes”, Working Paper, No. 2017:9, Uppsala University Department of Economics.

Lutz, W. et al. (2018), Demographic and Human Capital Scenarios for the 21st Century: 2018 assessment for 201 countries, Publications Office of the European Union. 
Maravalle, A. and $Ł$. Rawdanowicz (2018), "To shorten or to lengthen? Public debt management in the low interest rate environment", OECD Economics Department Working Papers, No. 1483, OECD Publishing, Paris, https://doi.org/10.1787/192ef3ad-en.

Mauro, P. and J. Zhou (2020), "r minus g negative: Can We Sleep More Soundly?", IMF Working Paper, No. 20/52, International Monetary Fund, Washington, D.C., https://www.imf.org/en/Publications/WP/Issues/2020/03/13/r-minus-g-negative-Can-WeSleep-More-Soundly-49068?cid=em-COM-789-41272.

OECD (2021), OECD Economic Outlook, Volume 2021 Issue 1: Preliminary version, OECD Publishing, Paris, https://dx.doi.org/10.1787/edfbca02-en.

OECD (2020), Promoting an Age-Inclusive Workforce: Living, Learning and Earning Longer, OECD Publishing, Paris, https://doi.org/10.1787/59752153-en.

OECD (2019), Pensions at a Glance 2019: OECD and G20 Indicators, OECD Publishing, Paris, https://dx.doi.org/10.1787/b6d3dcfc-en.

OECD (2017), Bridging the Gap: Inclusive Growth 2017 Update Report, OECD Publishing, Paris, http://www.oecd.org/inclusive-growth/Bridging the Gap.pdf.

OECD (2014), "Growth Prospects and Fiscal Requirements Over the Long Term", in OECD Economic Outlook, Volume 2014 Issue 1, OECD Publishing, Paris, https://dx.doi.org/10.1787/eco outlook-v2014-1-44-en.

OECD (2014), OECD Economic Surveys: India 2014, OECD Publishing, Paris, https://doi.org/10.1787/eco surveys-ind-2014-en.

Orszag, P., R. Rubin and J. Stiglitz (2021), "Fiscal Resiliency in a Deeply Uncertain World: The Role of Semiautonomous Discretion", Policy Brief, No. 21-2, Peterson Institute for International Economics, Washington, D.C., https://www.piie.com/sites/default/files/documents/pb21-2.pdf.

Price, R., T. Dang and J. Botev (2015), "Adjusting fiscal balances for the business cycle: New tax and expenditure elasticity estimates for OECD countries", OECD Economics Department Working Papers, No. 1275, OECD Publishing, Paris, https://dx.doi.org/10.1787/5irp1g3282d7en.

Rachel, L. and T. Smith (2015), "Secular drivers of the global real interest rate", Bank of England Staff Working Papers, No. 571, Bank of England, London.

Rachel, L. and L. Summers (2019), "On Falling Neutral Real Rates, Fiscal Policy, and the Risk of Secular Stagnation", Brookings Papers on Economic Activity Conference Drafts, Brookings.

Rouzet, D. et al. (2019), "Fiscal challenges and inclusive growth in ageing societies", OECD Economic Policy Papers, No. 27, OECD Publishing, Paris, https://doi.org/10.1787/c553d8d2en.

Ruch, F. (2020), "Policy Challenges for Emerging and Developing Economies: Lessons from the Past Decade", World Bank Policy Research Working Paper, No. 9180, World Bank, Washington, D.C., http://documents.worldbank.org/curated/en/docsearch/documenttype/620265.

Standard and Poor's (2016), Global Aging 2016: 58 Shades Of Gray, Standard and Poor's. 
Turner, D. et al. (1998), "The Macroeconomic Implications of Ageing in a Global Context", OECD Economics Department Working Papers, No. 193, OECD Publishing, Paris, https://doi.org/10.1787/502646045314.

Turner, D. and H. Morgavi (2021), "Revisiting the effect of statutory pension ages on participation and the average age of retirement in OECD countries", Public Sector Economics, Vol. 45/2, pp. 257-82, https://doi.org/10.3326/pse.45.2.4.

Wyplosz, C. (2019), Olivier in Wonderland, VoxEU, https://voxeu.org/content/olivier-wonderland. 


\section{Annex. The growth projection and accounting framework}

\section{Model coverage and aggregates}

The long-term model includes 48 countries: the 38 OECD member countries, eight non-OECD G20 countries (Argentina, Brazil, China, India, Indonesia, Russia, Saudi Arabia and South Africa) and two other accession or partner countries (Bulgaria and Romania).

In tables and figures, the ' $\mathrm{G} 20$ advanced' aggregate includes Australia, Canada, Germany, France, the United Kingdom, Italy, Japan, Korea and the United States. The 'G20 emerging' aggregate includes Argentina, Brazil, China, India, Indonesia, Mexico, Russia, Saudi Arabia, Turkey and South Africa. The 'OECD + G20' aggregate includes all OECD and non-OECD G20 countries, which together amount to approximately $82 \%$ of total world GDP at Purchasing Power Parities.

\section{Potential output projection}

The backbone of the model is a consistent set of long-run projections for potential output which are extensions of the short-term potential output estimates prepared for the twice-yearly OECD Economic Outlook following the approach described in Chalaux and Guillemette $\left(2019_{[28]}\right)$. Potential output ( $Y$ ) is based on a Cobb-Douglas production function with constant returns to scale featuring physical capital $(K)$ and trend employment $(N)$ as production factors plus labour-augmenting technological progress $(E$, hereafter referred to as trend labour efficiency ${ }^{15}$ ), so that:

$$
y=\alpha(n+e)+(1-\alpha) k
$$

where lower case letters denote logarithms and $\alpha$ is the labour income share, assumed to be 0.67 for all countries. ${ }^{16}$ Potential output is projected out to 2060 by modelling the trend input components as follows:

- Labour efficiency growth is determined in a conditional convergence framework. In the long run, it converges to an assumed exogenous rate of global technological progress ( 1 per cent per annum). In steady state, the equilibrium level of labour efficiency depends on the particular institutional and policy environment of each country represented by: a broad governance indicator (the World Bank's rule of law indicator); the stock of human capital (mean years of schooling in the population aged 15 and over adjusted for decreasing marginal returns to education); the extent to which product market regulation promotes competition (the OECD's PMR index); the stability of the macroeconomic environment (based on the level and volatility of inflation); trade openness (adjusted for population size); the stock of domestic and global R\&D; and income inequality (the GINI coefficient). Two of these indicators - the quality of governance and trade openness - affect not only the equilibrium labour efficiency level, but also the speed at which countries converge to this level. For average values of both indicators, the speed of convergence is about $2.3 \%$, meaning that this proportion of the distance between the current labour efficiency level and the equilibrium is eliminated each year. Convergence is also influenced by momentum given current estimates of

\footnotetext{
${ }^{15}$ In this framework, labour efficiency $(E)$ and total factor productivity $(T F P)$ - that part of output not explained by factor inputs - are closely related but distinct concepts: $T F P=E^{\alpha}$.

${ }^{16}$ This parameter value roughly corresponds to the wage share in advanced economies and has proven to be quite stable in time. This is less true of emerging market economies, however, and future work could consider the consequences of allowing the wage share to vary across country, over time, or both. See Chalaux and Guillemette $\left(2019_{[28]}\right)$ for more on this assumption.
} 
trend labour efficiency growth specific to each country. The baseline scenario assumes no change to explanatory variables, except for average educational attainment, which rises mechanically as younger generations with more education gradually replace older ones. Educational attainment projections are based on the SSP2 scenario of Lutz et al. (2018[29]), which combines medium fertility, mortality and migration assumptions (similar to the population projections) with their Global Education Trend (GET) scenario. The GET is a moderately optimistic scenario, considered most likely, which assumes that countries will follow the average path of educational expansion that other countries, already further advanced in this process, have experienced. For more details on the productivity convergence framework see Guillemette et al. (2017[30]).

- The evolution of trend employment is primarily the result of three sets of dynamics: the evolving size of the working-age population; its age composition; and trends in the employment rates of different age/sex groups. The size and composition of the working age population (15-to-74 yearolds) follows the population projections of Eurostat (for most European countries) and the United Nations (for other countries) and are considered exogenous for this exercise. Trends in the employment rates of different age/sex groups are projected by applying a cohort approach to cyclically-adjusted historical employment rates. These generational trends reflect societal changes, such as rising female employment rates, but also structural changes such as higher educational attainment. Projected changes in potential employment arise from differences in the employment propensities of different cohorts combined with shifts in the demographic structure of the population. To take into account the impact of recent and future policy changes on trend employment rates, the approach also integrates OECD empirical estimates of the impacts of structural reforms (Égert and Gal, (2017 $\left[7_{[7]}\right)$; Gal and Theising, $\left(2015_{[6]}\right)$ ). For the baseline scenario, already-legislated future changes in legal retirement ages are taken into account. Other labour market policy indicators are held constant. For more on the trend employment projection framework, see Cavalleri and Guillemette (2017[31]).

- The productive capital stock is notionally split between private and public sector capital stocks. The public sector capital stock-to-output ratio is assumed to be constant in the baseline scenario and thus does not affect the projection, but public investment shocks can be simulated in alternative scenarios. The projection of the business sector capital stock incorporates a measure of momentum for smoothness purposes but ensures that in steady state, the capital-to-output ratio is stable, so that the growth contribution from changing capital intensity is usually modest, in line with a stylised fact from growth decompositions (Jones, 2015[32]). The projection also incorporates influences from the economy's cyclical position, product market regulation, employment protection legislation and the user cost of capital, the latter changing somewhat in the baseline scenario following the path of interest rates, while the other policy indicators are assumed fixed. Business sector investment is derived from the capital stock projection via the stock-flow identity using a simple projection rule for the depreciation rate. Housing is excluded from the definition of the productive capital stock. For more on the capital stock projection framework, see Guillemette, de Mauro and Turner (2018[33]).

\section{Decomposition of per capita real GDP growth}

A convenient expository decomposition (used in Table 1 in the main text) is to divide changes in GDP per capita, a crude metric for living standards, into productivity, capital intensity and labour utilisation components:

$$
\Delta(y-p)=\alpha \Delta e+\{1-\alpha\} \Delta(k-n)+\Delta(n-p w a)+\Delta(p w a-p)
$$

where $P$ is total population, $P W A$ is population of working age (defined here as ages 15 to 74 ), and lowercase letters again denote logarithms. The first term on the right-hand side of this equation measures the contribution of labour efficiency growth to GDP per capita growth; the second term measures the contribution of capital intensity (capital per worker); the third picks up the contribution of the employment 
rate; and the last term indicates the contribution of the share of the population that is of working-age, a summary indicator of the population age structure.

\section{Exchange rate for currency conversion}

When comparing levels across countries, GDP and GDP per capita are expressed in United States dollars (USD) at fixed 2015 Purchasing Power Parity (PPP) exchange rates.

\section{Main policy channels in the model}

This diagram illustrates the policy channels incorporated in the long-term model:

\section{Policy channels in the long-term model}

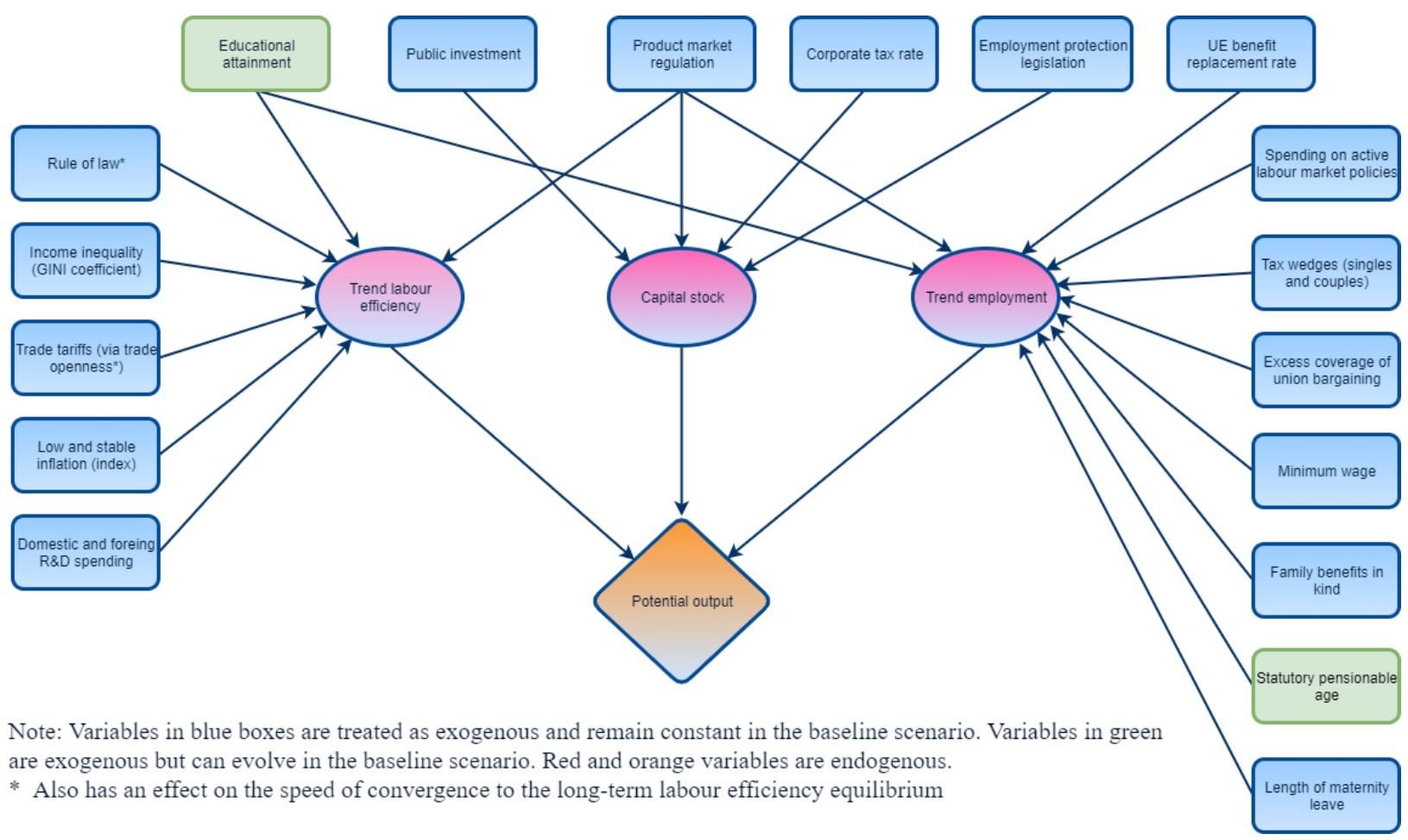

\section{Caveats regarding the interpretation of projections and scenarios}

First, the scenarios are highly stylised, conditional on a number of hypotheses and omit some important factors, such as the environment. They are not meant to be realistic but to illustrate some of the forces that could shape the medium and long-term outlook for the world economy. As regards missing elements, the projections should be seen as incorporating the implicit assumption that they remain unchanged from their current states. Second, long-run scenarios are useful, but not always sufficient, to provide country-specific policy recommendations, which must take account of particular economic and policy contexts that cannot be fully incorporated into such a stylised exercise. Third, differences in economic outcomes between the baseline and alternative scenarios incorporating policy changes should not be interpreted as reflecting pure one-way causation from policies to outcomes. In reality, causation typically runs both ways, so the coefficients linking policies and outcomes incorporated in the long-term model should be understood as attempts to add realism to the scenarios, in the sense of respecting estimated historical correlations. Fourth and finally, the long-run scenarios focus on GDP per capita as a measure of living standards and leave out many other dimensions of well-being. The long-term scenarios can and should be considered in conjunction with other projection exercises - for the environment, income inequality, health, etc. - to get a full picture of the likely evolution of well-being. 